\title{
MAKING THE HUMAN RIGHTS TALK MATTER: ARE THE BRAZILIAN STATE'S PRACTICES REALLY FOLLOWING ITS RHETORIC TOWARDS THE PROTECTION OF HUMAN RIGHTS DEFENDERS IN THE COUNTRY?
}

\author{
Ulisses Terto Neto ${ }^{1}$
}

\begin{abstract}
This paper considers the interplay of international law, politics and national law in the politics of human rights in Brazil through post- 1985 Brazilian democratic governments with reference to the foundation of a governmental culture of human rights as well as the institutionalization from 1964 to 2010 of international human rights law into the country's legal system. Drawing on Critical Discourse Analysis (CDA), it compares, on the one hand, international human rights instruments ratified by Brazil and, on the other hand, significant samples of human rights documents related to the Brazilian transition to democracy. By unveiling influences of the political, economic, social and cultural shifts (developments) towards the creation of the unprecedented Brazilian Programme for the Protection of Human Rights Defenders (PPDDH), it finally engages with the questions of whether the Brazilian State's practices follow its human rights rhetoric as well as whether the Brazilian State's practices are really following its human rights rhetoric towards the protection of human rights defenders in the country.
\end{abstract}

Keywords: The Politics of Human Rights; International Human Rights Law; Brazilian Programme for the Protection of Human Rights Defenders; Critical Discourse Analysis (CDA).

\section{INTRODUCTION}

While providing a brief reconstruction of the development of the Brazilian politics of human rights, ${ }^{2}$ the paper embarks on a critical-contextual discussion in order to (1) understand the surge of a governmental culture of human rights in Brazil, and (2) comprehend the shift from denial to acceptance and dialogue by Brazil's post-

\footnotetext{
${ }^{1}$ Law Lecturer, School of Law, Centro Universitario IESB (Brasilia/DF, Brazil). Researcher Member of the Centre for Citizenship, Civil Society and Rule of Law (CISRUL/University of Aberdeen, Scotland, United Kingdom). Researcher Member of the Group for Studies, Research and Extension about Democracy, Human Rights and Public Policies (Grupo de Estudos, Pesquisa e Extensão sobre Democracia, Direitos Humanos e Políticas Públicas-GDESI / UFMA, Brazil). E-mail: ulisses.terto.neto16@aberdeen.ac.uk

${ }^{2}$ The analysis of both Brazilian politics of human rights and world politics is conducted here within a constructivist perspective in connection with the historicity of human rights. Consequently, a historical approach towards the subject has been taken here starting from the coup d'état that brought in the military regime (1964-1985) in Brazil. Also, "[ ... ] historicity of human rights, to the extent in which they are not a given, but a construct, a human invention, which is in constant process of construction and reconstruction. As moral demands, human rights are fruit of a symbolic space of fights and social action, in search of human dignity, which compose an axiological emancipator construct. [...]", in Piovesan (2008, 109-110). See also Lafer (1988); Arendt (1976). For a constructivist perspective see Carlsneas et al (2003); Katzenstein et al (1999); Buzan and Little (2000); Klotz and Lynch (2007); Guzzini and Leander (2006); Wendt (2010) and Koerner (2003).
} 
1985 foreign policy, which favoured the progressive institutionalization of international and regional human rights instruments into the Brazilian legal system. Moreover, drawing on Critical Discourse Analysis (henceforth CDA) the paper then compares, on the one hand, international and regional human rights documents ratified or acceded by Brazil and, on the other hand, significant samples of human rights documents and official presidential manifestations related to the authoritarianism, transition to democracy, and formal democracy phases in recent Brazilian history. Further, the paper verifies whether Brazil's practices follow its human rights rhetoric. These factors are significant to comprehend the creation of the Brazilian Programme for the Protection of Human Rights Defenders (hereafter PPDDH). ${ }^{3}$ In this regard, while arguing for the existence of umbilical connections among the re-democratization of the country, internal and external pressures by NGOs and social movements ${ }^{4}$, and the surge, development and consolidation of a post-1985 Brazilian governmental culture of human rights, the paper considers Brazil's (Executive Branch's) response (s) to the demand for protecting human rights in general and human rights defenders (activists, militants, groups and/or human rights NGOs that promote and protect human rights) in particular. To do so, the paper examines the discursive construction of "human rights" in Brazilian foreign as well as internal policy documents and official manifestations that refer, directly or indirectly, to the promotion and protection of human rights and human rights defenders respectively. The understanding of Brazil's responses to human rights violations and, particularly, to state and non-state violence against human rights defenders might offer alternatives to face the still untouched pre-existing structures that have thwarted social justice in Brazil. Within this context, the first section presents a brief description of the CDA approach and an explanation regarding the corpus utilized for the analysis in this paper. The second section provides an overview of the politics of human rights in Brazil in light of the positive efforts by post-1985 Brazilian democratic administrations in regard to a governmental culture of human rights, as well as the institutionalization of international and regional human rights law into the country's legal system. The third section sheds light on the influences of the political, economic, social and cultural changes towards the creation of the PPDDH. The CDA methodology will be applied to the analysis. The fourth section argues for the existence of a set of causal chains that explain the PPDDH's establishment. Finally, the paper answers the question: Are the Brazilian State's practices really following its rhetoric towards the protection of human rights defenders in the country?

\section{SETTING THE PARAMETERS OF ANALYSIS (CDA APPROACH)}

It is commonly accepted that discourse reflects human representations that mark political, social, economic and cultural manifestations in any society. Whatever is said, silenced, manipulated, distorted, used or

\footnotetext{
${ }^{3}$ For a detailed account of the political history of the PPDDH's creation, modelling, and functioning see Terto Neto (2016 a).

4 "[ ... S Social movements have been deeply involved in this struggle since the very beginning of the resistance to the authoritarian vol.09, nº. 04, Rio de Janeiro, 2016. pp. 2263-2311 2264
} 
misused in discourses can also unveil traditions and contradictions that usually explain the set of circumstances that generate the power relations upon which societies are organized. This is so due to the fact we not only "act discursively, as also represent discursively the (social) world around us" (MAGALHÃES, 2005, 5). Thus, questions related to agency, ${ }^{5}$ structure and identity can be identified or recognized within discourses and this, undoubtedly, contributes to the claims for social change, both domestically and globally. ${ }^{6}$ One of the pivotal aspects of this paper refers to comprehending the contradictions between Brazil's human rights rhetoric and its governmental practices in response to persistent human rights violations in the country. Among various available approaches to analyse Brazil's human rights rhetoric, this paper applies $\mathrm{CDA}^{7}$ due to its theoretical and methodological pluralism. In fact, CDA offers a 'methodologically flexible framework deploying linguistic techniques in examining the way linguistic features - concepts, lexicalization, emplotment and semiotic processes in general - are involved in reproducing or challenging relations of power' (TETI, 2012, 268). Such approach allows for results of analysis to be 'compatible with several different analytical traditions, specifically bridging the positivist/post-positivist divide' (TETI, 2015, 10-11). It certainly gives much more room for the analyst to make use of a combination of multiple theoretical approaches in parallel with CDA. Brief comments on CDA and the corpus that has been constructed for the analysis conducted in this paper are made below.

\section{Understanding Critical Discourse Analysis (CDA)}

Usually Discourse Analysis (hereafter DA) works based upon epistemological premises that remind the analyst that (1) researchers cannot make predictions due to the complexity and dynamism of the social world, (2) there is no neutral and unique truth in social sciences, and (3) once there are as many truths as realities, so it is not possible to reach absolute truth (NOGUEIRA, 2001, 17). The understanding of these premises is crucial for anyone working with DA, for it is "better comprehended as a field of research than as a simple practice once it is possible to identify different approaches/conceptions" (NOGUEIRA, 2001, 23). In fact, it is important to consider that one of DA's main goals is to develop the "theoretical and methodological debate of discourse: the language as social practice" (MAGALHÃES, 2005, 2). Thus, it should be borne in mind that CDA is an approach

\footnotetext{
regime in the early 1970s", in Dagnino $(1998,46)$.

${ }^{5}$ One of the pillars of Discourse Analysis (DA) is the rescue of the subject (agent), who had apparently been forgotten by the structuralism tradition. The reencounter with this forgotten subject (agent) occurred via the combination of linguistic structuralism, psychoanalysis, and historical materialism and was highly inspired by the work of Michel Pecheux. See Ferreira (2003).

${ }^{6}$ This paper takes a critical approach towards Brazil's situation of persistent state and non-state violence against human rights defenders and, as a result, claims for social change in the country towards a new citizenship in the same line as sustained by Dagnino (1998).

${ }^{7}$ As Discourse Analysis (DA), the CDA looks for patterns, "but within ampler contexts, associated with societal or cultural questions. Its influences come from perspectives derived from the French structuralism and pos-structuralism, and from the works of Foucault, essentially his preoccupation with the relations between power and knowledge" in Nogueira $(2001,27)$.
} 
that can be chosen from within the field of DA. ${ }^{8}$ Following the tradition initiated with the work of Fowler et al (1979), who developed "a study of language approach known as Critical Linguistic (CL)” (MAGALHÃES, 2005, 2). Norman Fairclough coined the expression CDA for the first time in his 1985 paper. ${ }^{9}$ This does not mean, however, that CDA should be interpreted as an extension of CL. ${ }^{10}$ In reality, the opposite is true, for CDA not only studies social practices concerning power relations and ideology in societies, but also "offers a valuable contribution of linguists to the debate of questions linked to racism, discrimination based on sex, national identity, self-identity and gender identity, [ ... ] social exclusion” (MAGALHÃES, 2005, 3), and, let us add, state and nonstate violence against human rights defenders. Thus, $\mathrm{CDA}$ is undoubtedly controversial "because it involves the study of the power and the resistance, of the contestation and the fight" (NOGUEIRA, 2001, 28). Therefore, it is clear that CDA belongs to a critical field within social sciences and, as a result, implies the conducting of critical research on/towards social change (CHOULIARAKI AND FAIRCLOUGH, 1999). In this sense, the CDA approach helps identify the traditions and contradictions that are present in Brazilian structures through the comparison of Brazil's human rights rhetoric and practices. Moreover, it should be noted that "CDA can also help trace policy change, and add methodological depth to narrative analysis" (TETI, 2012, 4) of the political, economic, social and cultural developments that have occurred in recent Brazilian history (1964 to 2010) (Potter and Wetherell, 1987, 175).

Concerning the usefulness of CDA in terms of legal doctrine, the CDA approach helps comprehend the connection between the (political, economic, social, and cultural) context and the observed phenomenon (object of study). Furthermore, the CDA approach also helps imagine alternatives by challenging the received story, that is, it makes it possible for the analyst to construct other alternatives and implications to explain the observed phenomenon. Both of these aspects are relevant to this paper. In addition, CDA recognizes that there is a normative dimension to any analysis, whether scientific or otherwise. This is to say that CDA recognizes that there is always a normative commitment to the importance of any study, particularly of those regarding ideology, interaction, power relations, and social change. The same phenomenon occurs within this paper, given its author

\footnotetext{
8 "The DA works with meaning and not with the content of the text, a meaning that is not translated, but produced; it can be affirmed that the corpus of the DA is constituted by the following formulation: ideology + history + language. $[\ldots]$ Therefore, in DA the language goes beyond the text, bringing meanings pre-constructed which are echoes of the memory of saying. It is understood as memory of saying the inter-discourse, that is, the socially constructed collective memory; the subject (agent) has the illusion of being the owner of his or her discourse and of having the control over it, but he or she does not realise being inside of a continuum, because every discourse has already been said before. [... ]", in Caregnato and Mutti (2006, 680-681).

${ }^{9}$ His paper is considered a seminal one in the field of DA. See Fairclough (1985); Magalhães (2005).

10 "Originated in the field of philosophy and human sciences, Discourse Analysis (DA) brought the well marked line of rupture, which has to do with its entry in the epistemological sphere of social sciences and with the form of political intervention that represented its creation. With the Saussurian cut of language/speech of the language/discourse there was a definitive change of terrain of the language and its statute in the discursive bias. Thus happened the rupture with linguistics, as it had already occurred with the social sciences, considered, then, positivist sciences that treated the language and the subjects (agents) as stable, homogeneous, centred notions." in Ferreira (2003, 42-43).
} 
has been an observer-participant in Brazilian social struggles for the promotion, protection and fulfilment of human rights in general, and the protection of human rights defenders in particular. In other words, the conduction of the CDA approach helps establish normative connections not only between text and context, but also among research, topic(s), and the context from where the researcher comes.

\section{The corpus of Analysis}

In order to comprehend Brazil's human rights rhetoric a corpus of analysis has been constructed. The corpus has been constructed having in mind the necessity to conduct two levels of analysis concerning Brazil's practices and human rights rhetoric, that is, one global and another domestic. ${ }^{11}$ At the international level, the analysis will cover documents on human rights (United Nations (UN) and Organization of American States (OAS) Human Rights Instruments ratified or acceded by Brazil) and official speeches delivered by Brazil at the United Nations ${ }^{12}$ (UN General Assembly Ordinary Sessions). At the national level, the analysis will cover significant samples of human rights documents related to the authoritarianism, transition to democracy and formal democracy phases in recent Brazilian history as, for instance, official presidential manifestations (Brazilian Presidential Inauguration speeches ${ }^{13}$ ), the country's reports to UN Treaty Bodies, Presidential Decrees, Bills, Federal Laws and so forth. The construction of the corpus of analysis is thus an ongoing process, which includes documents on human rights (universal declaration of human rights, international and regional human rights treaties, Brazil's country reports, Brazil's UPR reports, and so forth); documents on Brazilian foreign policy (official speeches by the President of Brazil and Minister of Foreign Affairs); and relevant human rights NGOs'speeches and reports.

\section{AN OVERVIEW OF THE POLITICS OF HUMAN RIGHTS IN BRAZIL}

Despite the passing of twenty-nine years since the authoritarian regime collapsed, the transition to formal democracy, and significant attempts to build up a governmental culture of human rights, ${ }^{14}$ it is evident that consistent human rights violations are still present throughout Brazil. Over the last fifty years, Brazil has gradually overcome a military dictatorship (1964-1985), promulgated a democratic Constitution (1988), realized seven

\footnotetext{
${ }^{11}$ The two levels of analysis will be confronted in order to unveil traditions and contradictions in regard to Brazil's practices and human rights rhetoric from 1964 to 2010. The final critical narrative will derive from a combination of both analyses.

${ }^{12}$ The longevity of these official discursive manifestations contributes to the identification of continuities and discontinuities in regard to Brazil's human rights discourse internationally as well as domestically.

${ }^{13} \mathrm{Ibid}$.

${ }^{14}$ In a parallel with the surge of a culture of human rights, which, as many argue, was originated as a positive fact of the postHolocaust world, it is sustained here that the Brazilian governmental culture of human rights is a positive fact of the post-1985 new democratic period. See Picq (2004); Rabossi (1990).
} 
free and direct presidential and legislative elections (1990-1994-1998-2002-2006-2010-2014), stabilized its economy, ${ }^{15}$ and, consequently, made considerable efforts to improve its democracy. ${ }^{16}$ Nonetheless, irrespective of all socio-political and economic advancements that have occurred in its recent history, the country is still struggling with endemic corruption, systemic violence, poverty, exclusion and inequality (PINHEIRO, 1998; PANIZZA AND BRITO, 1998), all of which can be summarized in a persistent context of social authoritarianism and unequal distribution of wealth (DAGNINO, 1993; 1994; 1998; 2000; 2001; 2007). ${ }^{17}$ The logical inference is that this is also the context in which social struggles for human rights and democracy are still occurring on a daily BASIS (ALVAREZ ET AL, 1998; DOIMO, 1995; GOHN, 1997). To understand this complex context, however, one must take note of the history since 1985 of Brazilian efforts towards the establishment of a governmental culture of human rights. ${ }^{18}$ Although progressive in its nature, this dynamic process has been marked by several contradictions and setbacks. ${ }^{19}$

\section{Authoritarianism}

A military coup d'état in 1964 introduced a dictatorial regime (31 March 1964-15 March 1985) and constitutional guarantees in Brazil ceased. Although some degree of legal institutionalism could be identified in the conduct of state affairs (Judiciary, Executive and Legislative branches), the absence (suspension) of a promulgated and, therefore, legitimate constitution ${ }^{20}$ impeded any illusion of normality in public or private affairs. Although human rights defenders ${ }^{21}$ organized and carried out various fights for democracy and human rights, the state

\footnotetext{
${ }^{15}$ The stabilisation of the economy persisted through the two Lula administrations and started going down through the Rousseff Administrations. The Centre for Economics and Business Research <http://www.cebr.com/> accessed 20 October 2016.

${ }^{16}$ For an accurate account of the 'parliamentarian coup' that suspended President Rousseff see Proner et al (2016). For an account of recent Brazilian history, see: Bueno (2010); Del Priore and Venâncio (2010); Martins Filho (2011); Gaspari (2003); Campos (1988); Meade (2010); Luna and Klein (2006); McCann (2008).

${ }^{17}$ Indicators can be found at the Brazilian Institute for Geography and Statistics (IBGE in Portuguese, http://www.ibge.gov.br/home/) and the Institute for Applied Economic Research (IPEA in Portuguese www.ipea.gov.br). The analysis is conducted here relating formal democracy and the effective exercise of constitutional fundamental rights.

${ }^{18}$ It is accepted here that the establishment of this governmental culture of human rights derives from the dialectical relations that occur between subjects (agents) from dominant and dominated sectors in their fights for economic, political and symbolic powers toward the establishment of hegemony within the Brazilian society. In any case, it is accepted here that the responsibility to tackle this social question rests upon both State and civil society. The former is taken here under the Gramscian perspective of an "amplified state". The latter is taken here as an arena of politics. Therefore, "the emphasis of the theory of hegemony on civil society as an arena of politics implies not a dichotomy but precisely a continuity between state and civil society”, in Dagnino (1998, 41).

${ }^{19}$ The analysis of the process has been brief. For a more detailed one see Terto Neto (2016 a, Chapter 2).

${ }^{20}$ The 1967 Brazilian Constitution was a granted semi-constitutional charter and imposed by the Military Regime, which forced the Brazilian Congress to approve it in order for the authoritarian regime to be "legalized". The 1969 Brazilian Constitution was indeed a Constitutional Amendment (Emenda Constitucional n. 1) to the 1967 Brazilian Constitution; despite some Brazilian scholars argue it was a granted constitution. In any case, once elaborated during the Military Regime, both constitutional documents lacked legitimacy. See Mendes et al (2008). For an academic account of authoritarian legalism in Brazil and Latin America see Pereira (2003 and 2005).

${ }^{21}$ I understand the term human rights defenders as explained in Terto Neto (2016 a). Thus, I not only adopt the term human rights defenders to refer to a person, group or entity that is "doing something" for the protection, promotion and/or defence of human vol.09, nº. 04, Rio de Janeiro, 2016. pp. 2263-2311 2268
} 
response was oppression and violence against them, with thousands of activists and supporters ${ }^{22}$ being arrested, tortured and killed by the state repression. ${ }^{23}$ In this scenario, therefore, it is pointless to talk about any governmental culture of human rights, for there was none. Indeed, the position of the dictatorial regime was one of denial concerning the existence of human rights violations in the country (PINHEIRO, 1999).

\section{Transition to Democracy}

The transition from authoritarianism to formal democracy started with the indirect election of the popular candidate Tancredo Neves, which was carried out by an electoral college. With Tancredo Neves' suspicious sickness and death in 1985, the vice-president, José Sarney, an oligarch politician from the Northeastern State of Maranhão and a notorious supporter of the military regime, ${ }^{24}$ was sworn in as the first civilian President of Brazil after the military coup d'état. In general, the key elements of this period were the resumption of a civilian politician as the controller of the Federal Government (1985), the realization of a National Constitutional Assembly (1987) and the promulgation of a new democratic Constitution (1988). ${ }^{25}$ Under the Sarney Administration (21 April 1985 - 15 March 1990) the seeds for a governmental culture of human rights were planted, ${ }^{26}$ at least when it comes to the Brazilian foreign policy. ${ }^{27}$ In spite of having been predominantly restrained to the level of human rights rhetoric, the Sarney Administration's attempts to put an emphasis on human rights issues while conducting its foreign policy could be explained by the fact that after having overcome a dictatorship that denied the existence of human rights violations in the country, Brazil needed to reconstruct its

\footnotetext{
rights, but also understand that Brazilian human rights defenders 'come from varied backgrounds including human rights activists, members of the clergy, relatives of victims, community leaders, trade unionists, environmental activists, students, academics, lawyers, journalists and some civil servants. While many defenders work within civil society organisations, much of the human rights defenders activity in Brazil is rooted in grassroots social movements that have organised at the state and federal level to enhance their impact on the local and national policies. [... ]' in E/CN.4/2006/95/Add.5 (2006: Paragraph 246, page 50).

${ }^{22}$ They were union leaders, professors, students, artists, among others.

23 "Under military authoritarian rule in Brazil, as in the rest of the Southern Cone, human rights violations were the product of a highly centralized state-sponsored plan which deliberately aimed to eliminate those which the military deemed to be enemies of the state. The motivation for violations was overwhelmingly political; people were killed, tortured or 'disappeared' for political reasons and their socio-economic background was largely irrelevant. [...]" in Panizza and Brito (1998, 23). For a detailed account of the political repression conducted by the military regime (1964-1985) in Brazil see Arns (2003).

${ }^{24}$ For an account of Sarney family's oligarch practices in the State of Maranhão and Brazil see Dória (2009); Gonçalves (2000).

${ }^{25}$ Despite all controversies and justified doubts, President Sarney did not obstruct the works of the National Constitutional Assembly (1987). As representatives of all sectors of society were present, the promulgation of the 1988 Brazilian Constitution occurred through a democratic and participative process by any means. This was a true division point in recent Brazilian history, for the Brazilian Magna Carta of 1988 introduced various constitutional guarantees for all fundamental rights that had been ignored or inexistent during the military regime, especially against the State itself.

${ }^{26}$ To which extent Sarney Administration envisaged and, therefore, consciously worked to make Brazil a bigger player in the global arena is still uncertain.

27 "Brazilian foreign policy during that period followed a dynamic which could be characterised as a 'dual approach': continuity, directly related to the geographic location and dimension of the country and to its insertion in the international community; and innovation, which became possible as a consequence of democratisation. Human rights was precisely the area which was most affected by the new orientation of Brazilian foreign policy. But we cannot yet speak of a genuine new course because the legacy of vol.09, no. 04, Rio de Janeiro, 2016. pp. 2263-2311 2269
} 
image in order to claim a place among the democratic nations of the world. ${ }^{28}$ In this respect, it seems that the Sarney Administration was aware of the importance of changing Brazil's global image for the pavement of a solid avenue towards the fulfilment of Brazilian aspirations concerning its acceptance as a new democracy by the international community. Nevertheless, it would be inaccurate to affirm that there was already any kind of governmental culture of human rights, for there was still none. Perhaps due to its ineffective management of the economy (Cruzado Plans failed and hyper inflation persisted), ${ }^{29}$ internal politics (negotiations regarding constitutional reforms and the consolidation of the transition to formal democracy), and its predominantly rhetorical initiatives toward human rights issues, the Sarney Administration ended facing a generalized "disenchantment with the new political order" (PANIZZA, 2000, 180). This led to a crisis of representation and could be indicated as one of the reasons for the surge of Fernando Collor de Mello, a charismatic, neo-populist leader (PANIZZA, 2000; SOARES, 1990). With a discourse posing himself as the only candidate capable of establishing a new and economically stabilized order, ${ }^{30}$ in contrast with the chaotic existing public (dis)order under the Sarney Administration, Collor became the first civilian president directly elected after the authoritarian period and "assumed the presidency with a high degree of legitimacy" (PANIZZA, 2000, 183). Therefore, his direct election completed the shift from authoritarianism to formal democracy in Brazil.

\section{Formal Democracy}

Under the Collor Administration (15 March 1990 - 29 December 1992) the governmental culture of human rights started shaping into something more concrete. In response to transnational NGOs' reports ${ }^{31}$ on the situation of gross human rights violations in the country and aware of the negative effects of NGOs' "naming and shaming" strategy ${ }^{32}$ on Brazil's image abroad, the Collor Administration took concrete actions ensuring the investigation of human rights violations cases denounced in those reports. This "constituted a departure from previous policy, whereby federal authorities would refuse to investigate human rights violations on the grounds that it was the responsibility of state and local authorities to do so" (PANIZZA AND BRITO, 1998, 27). In spite of this, emphasis should be put on the fact that under the Collor Administration human rights were included in

\footnotetext{
continuity would prevail through the Sarney government, limiting bold initiatives. [ ... ]", in Pinheiro (1999, 5).

${ }^{28}$ Panizza and Brito (1998).

${ }^{29}$ For the Cruzado Plan see Flynn (1986).

30 " [... ] allegedly, the country's conservative establishment 'manufactured' Collor as a candidate when faced with the possibility of an electoral contest between two equally untrustworthy and unpalatable candidates: The left-wing former trade unionist Luiz Inacio Lula da Silva and the veteran populist Leonel Brizola. Eventually, Collor, with the help of some dirty tricks and the overwhelming support of the country's largest television network, the Rede Globo, was able to snatch the narrowest of victories in a run-off against Lula", in Panizza $(2000,177)$.

${ }^{31}$ Particularly those that were provided by Amnesty International, available at: Amnesty International <http://www.amnesty.org/en> accessed 20 October 2016.

32 For an analysis of the relationship between global 'naming and shaming' efforts and governments' human rights practices see vol.09, no. 04, Rio de Janeiro, 2016.pp. 2263-2311 2270
} 
the presidential political agenda as a result of national and transnational human rights advocacy groups' political pressure "from below" and "from above" (BRYSK, 1993). Therefore, one should perceive the Collor Administration's efforts towards human rights issues, which also resulted in Brazil's ratification and accession of international human rights instruments during the period, ${ }^{33}$ as "largely defensive and based on the politics of shame” (PANIZZA AND BRITO, 1998, 27). Moreover, the Collor Administration's key elements were the pursuit of the modernization of Brazilian economy (combating inflation, Collor Plans, privatization and liberalization) and President Collor's risky strategy of accepting no political negotiations towards its progressive economic and political agenda (PANIZZA, 2000, 180). The latter eventually led to his downfall. In fact, within a new conjuncture in which national and transnational civil society organizations possessed significant influence in the struggles for fundamental rights and the consolidation of democracy, the Collor Administration `s failure to stabilize the economy as well as unsuccessful attempts to implement a neo-populist political agenda led to the impeachment process by the Brazilian Congress (PANIZZA AND BRITO, 1998). In any case, the increased importance of human rights in Brazilian internal and external politics under the Collor Administration occurred "not only for ethical reasons, but because Brazil could not seriously pursue an influential role in multilateral institutions if it continued to disregard human rights" (PINHEIRO, 1999, 12). Consequently, it is generally accepted that the seeds of a governmental culture of human rights that were planted under the Sarney Administration started germinating under the Collor Administration. Their flourishing would occur later on under the Cardoso and Lula Administrations.

Yet, it is necessary to stress that in spite of the political impeachment process against President Fernando Collor de Mello, the Brazilian just-reborn democracy was not destabilized, even though concerns about a return of military rule were manifest. ${ }^{34}$ In fact, the opposite is true, for "Collor's impeachment was an exercise in democratic accountability that showed the considerable strength of civil society as a check on personalist rule" (PANIZZA, 2000, 189). This means that when the vice-president, Itamar Franco, was sworn in as President of Brazil, human rights discourse was already broadly recognized, despite violations still occurring all around the country. As a result, it is possible to identify significant progress under the Franco Administration (29 December 1992 - 31 December 1994) concerning a governmental culture of human rights. Indeed, the Franco Administration "demonstrated a clear commitment to the continuing process towards greater transparency and more pro-active human rights policies" (PINHEIRO, 1999, 15). Pressured by national public opinion concerning, for instance, the

Hafner-Burton (2008).

${ }^{33}$ For a list of the international and regional human rights instruments ratified by Brazil in the 1990 s see Table 2 below.

34 "Pursuant to the procedures set forth in the new Constitution, Fernando Collor de Mello was elected president by universal suffrage and the democratic regime began to be consolidated. In 1992, the Federal Senate instituted the political impeachment of Collor de Melo. The proceeding ended when he resigned in that same year, and Vice President Itamar Franco assumed the presidential office. The events of the crisis were handled with punctious legality, thus attesting to the political maturity and democratic awareness of the Brazilian people" in OEA (2006, Paragraph 9). 
Candelária ${ }^{35}$ and Yanomani ${ }^{36}$ massacres, as well as influenced by global echoes from the Vienna Conference on Human Rights (1993), ${ }^{37}$ the Franco Administration attempted to conduct serious reforms regarding human rights programmes and policies, including measures such as the launching of a National Programme for the Promotion of Citizenship and to Combat Violence, ${ }^{38}$ the reorganization and re-structuring of the Council for the Defence of the Rights of the Human Person ${ }^{39}$, and a set of bills. ${ }^{40}$ Although they were serious, the Franco Administration's attempts did not manifest in concrete changes that could really challenge the historical culture of violence present in Brazil. ${ }^{41}$ Irrespective of its efforts and perhaps due to President Franco's well-known nationalist character, the Franco Administration "remained largely reactive, consisting primarily of exercises in damage limitation after particularly serious human rights crimes" (PANIZZA AND BRITO, 1998, 28). Nonetheless, the Franco Administration's major achievement was the stabilization of the Brazilian economy, which eventually assured the election of his successor, Fernando Henrique Cardoso. ${ }^{42}$

Under the Cardoso Administrations (01 January 1995 - 31 December 2002) the governmental culture of human rights was developed considerably. ${ }^{43}$ Indeed, from the beginning of the Cardoso Administrations not only did human rights become part of the official agenda and presidential public statements, but also concrete governmental efforts were undertaken in order to combine official human rights discourse and state practices (PANIZZA AND BRITO, 1998; PINHEIRO, 1999 AND 1998). President Cardoso's understanding that noncompliance with international human rights standards would jeopardise Brazil's aspirations to become a bigger player in world trade and politics led the Cardoso Administrations to engage in transparent dialogue with civil society actors, as well as to open the country to monitoring of rights mechanisms by both global (United Nations) and regional (Organization of American States) systems multilateral organizations (CAVALLARO, 2002; PANIZZA AND BRITO, 1998; PINHEIRO, 1999 AND 1998). Following this trend, it is important to consider as key elements of Cardoso Administrations' the following: the stabilization of the economy under neoliberal

\footnotetext{
35 The Candelária massacre refers to summary executions of children and adolescents (eight in total) by police that occurred in 1993 nearby the Candelária Chuch in Rio de Janeiro, RJ, Brazil.

36 The Yanomani or Haximu massacre refers to armed conflicts between the Yanomani indigenous people and miners that occurred in 1993 in Roraima, Brazil, from which many members of the Yanomami Haximu-teri tribe and a few miners were killed.

${ }^{37}$ The Vienna Declaration and Plan of Action can be found at The United Nations <http://www.unhchr.ch/huridocda/huridoca.nsf/(symbol)/a.conf.157.23.en> accessed 20 October 2016.

${ }^{38}$ It was not advanced due to political factors that prevented legislative proposals (bills) that would enhance it from being passed into Law by the Brazilian Congress. See Pinheiro (1998).

${ }^{39}$ With the advent of Lei no 12.986/2014, the Council for the Defence of the Rights of the Human Person was turned into the National Human Rights Council. Presidência da República <http://www.sedh.gov.br/clientes/sedh/sedh/conselho/pessoa_humana> accessed 20 October 2016.

${ }^{40}$ They were never analysed by the Brazilian Congress. See Panizza (2000).

${ }^{41}$ The analysis is taken here in observance of pre-existing structures and lack of development. See Moser and Mcllwaine (2006).

${ }^{42}$ Fernando Henrique Cardoso was the Ministry of Finance under Franco Administration.

${ }^{43}$ With the consolidation of the economic stability plan under a neoliberal perspective, President Cardoso was then re-elected in 1998, staying in office until 2002. Even under a neoliberal agenda, President Cardoso advanced the human rights agenda. See Pinheiro (1999).
} 
economic reforms; transparency and dialogue with civil society on human rights matters; submission of various bills on the protection of human rights, particularly directed to reorganizing the Council for the Defence of the Rights of the Human Person, ${ }^{44}$ creating a Protection Programme for Threatened Witnesses and typifying torture (PANIZZA AND BRITO, 1998); launching of a Human Rights Annual Prize; ${ }^{45}$ and the elaboration and launching of the National Programme for Human Rights, ${ }^{46}$ among others (MACAULAY, 2007; PANIZZA AND BRITO, 1998; PINHEIRO, 1999 AND 1998. Therefore, under the effects of different sources of influence the Cardoso Administrations created an important institutional domestic architecture for human rights (MACAULAY, 2007). ${ }^{47}$ Even though by the end of the second Cardoso Administration human rights violations were still massively occurring, its administrative-political efforts materialized and advanced the Brazilian governmental culture of human rights significantly.

If, on the one hand, the first five post-1985 democratic governments - the Sarney, Collor, Franco, and two Cardoso administrations - were significant for the surge and subsequent development of a Brazilian governmental culture of human rights, sensitive to international standards as well as responsive to national and transnational civil society's pressures, on the other hand, the two Lula Administrations (01 January 2003 - 31 December 2010) were pivotal for the consolidation of the Brazilian State's human rights discourse and practices, both domestically and abroad. In fact, President Lula went further than his predecessors since he not only developed an internal politics ${ }^{48}$ directed to the creation of effective alternatives for combating poverty, hunger, inequality and social exclusion in the country, ${ }^{49}$ but also conducted an innovative and ambitious foreign policy that made Brazil seek the exercise of global leadership perhaps for the first time in its history. ${ }^{50}$ The election of Luis Inácio Lula da Silva as President of Brazil in 2002 should be perceived as another evidence of the strengthening of Brazilian democratic institutions since the country's transition from authoritarianism to formal democracy. With vast popular support, ${ }^{51}$ and professing that democracy and social equality are achievable, President Lula was then

\footnotetext{
${ }^{44}$ Ibid (n 38).

${ }^{45}$ Secretaria de Direitos Humanos da Presidência da República do Brasil <http://www.sedh.gov.br/clientes/sedh/sedh/promocaodh> accessed 20 October 2016.

${ }^{46}$ The National Programme for Human Rights was created according to recommendations by the Vienna Declaration on Human Rights and respective Programme of Action (1993). The United Nations <http://www.unhchr.ch/huridocda/huridoca.nsf/(symbol)/a.conf.157.23.en> accessed 20 October 2016.

47 " [ ... ] the influences on the Cardoso government's criminal justice and human rights initiatives came from various contradictory directions - from the international human rights regime and its domestic allies, from other multilateral agencies, and from homegrown moral conservatives and producer groups. The power of the latter allowed reform efforts to be derailed. [... ]" in Macaulay (2007:39).

${ }^{48}$ It is commonly observed that formal and informal institutions played an important role in the events that led to the scandals of corruption in the first Lula Administration. In fact, it is fair to infer that Brazilian democratic and governmental institutions are still in need of development, for corruption, nepotism and other negative aspects persist in a daily basis. Thus, the historical and unequal Brazilian structures must be transformed radically if an effective human rights regime were ever to occur in Brazil.

${ }^{49} \mathrm{Ibid}$ (n 16).

${ }^{50}$ For an overview of Brazilian foreign policy under Lula Administrations see Amorim (2010).

${ }^{51}$ One so strong that resisted even the scandals of corruption in the first Lula Administration.
} vol.09, no. 04, Rio de Janeiro, 2016.pp. 2263-2311 
re-elected in 2006 and stayed in office until 2010, when his candidate and successor, Dilma Rousseff, won the presidential election, took over the presidential office and was sworn in as the first woman President of Brazil. ${ }^{52}$

In spite of the fact that they did not bring the expected structural changes to Brazilian society, the two Lula Administrations nonetheless helped improve the image of Brazil both internally and abroad. Moreover, with a charismatic personality and innovative attitudes, President Lula helped not only change the way Brazilians perceived themselves, but also the way other nations perceived Brazil. No longer afraid of exploring their potential, Brazilians started believing in themselves. No longer suffering from a historical complex of inferiority ${ }^{53}$ and dependency ${ }^{54}$, Brazil, under Lula Administrations, started a pragmatic pursuit of its quest for world recognition not only economically, but also politically. ${ }^{55}$ This shift in domestic politics and the respective change in public and private attitudes within the country were significant for consolidating the Brazilian governmental culture of human rights and pivotal for Brazil's aspirations to become a bigger player in world politics under Lula Administrations. Table 1 describes Brazil's internal and external politics and its relation to the governmental culture of human rights. ${ }^{56}$

\section{Table 1-Brazil's Internal and External Politics and Governmental Culture of Human Rights}

\section{(1964-2010)}

\begin{tabular}{|c|c|c|c|}
\hline Government & Foreign Policy on Human Rights & Internal Politics & $\begin{array}{c}\text { Governmental } \\
\text { Culture of Human } \\
\text { Rights }\end{array}$ \\
\hline $\begin{array}{c}\text { Military } \\
\text { Regime } \\
(1964-1985)\end{array}$ & $\begin{array}{c}\text { Denial of the existence of human } \\
\text { rights violations. }\end{array}$ & Authoritarianism. & No \\
\hline $\begin{array}{c}\text { Sarney } \\
(1985-1990)\end{array}$ & $\begin{array}{c}\text { Acceptance of the existence of } \\
\text { human rights violations. }\end{array}$ & $\begin{array}{c}\text { Transition from dictatorship to } \\
\text { formal democracy. }\end{array}$ & $\begin{array}{c}\text { No, but human } \\
\text { rights rhetoric }\end{array}$ \\
\hline
\end{tabular}

${ }^{52}$ Although her victory occurred due to Lula's support and popularity, President Rousseff had tried to establish her own style and, this way, distance herself from her predecessor. Nonetheless, it is not secret that Lula has played an important role in Brazilian politics and that his support to President Rousseff was decisive in getting her re-elected in 2014. In any case, with the admissibility of the impeachment process by the Congress, President Rousseff was suspended and eventually impeached on 31 August 2016. For details on the 'parliamentarian coup' see Proner et al (2016). G1 <http://g1.globo.com/politica/processo-de-impeachment-dedilma/noticia/2016/08/senado-aprova-impeachment-dilma-perde-mandato-e-temer-assume.html> accessed 19 October 2016.

${ }^{53}$ An "under dog's house" complex that has made Brazilians think they are never good enough.

${ }^{54}$ The historical dependency Brazil has had on first Portugal, then the United Kingdom and the USA. In spite of its strong economic connections with both the USA and the UK, Brazil is today, nonetheless, trying to follow its own path in order to diminish the aforementioned dependency. The idea is to depart from an unequal relationship to a more balanced one, that is, to shift from dependency to cooperation or partnership among equals. Brazil's participation in the BRICS is a good example in this regard.

${ }^{55}$ This occurred irrespective of and in parallel with scandals of corruption during the first Lula Administration.

${ }^{56}$ I organised the table drawing my interpretations from the following sources: Panizza and Brito (1998); Piovesan (2008); Pinheiro (1998 and 1999); Macaulay (2007); Picq (2004); Alves (2011). 


\begin{tabular}{|c|c|c|c|}
\hline & $\begin{array}{l}\text { Seeks the acceptance of the } \\
\text { global community. }\end{array}$ & & already existed. \\
\hline $\begin{array}{c}\text { Collor } \\
(1990-1992)\end{array}$ & $\begin{array}{l}\text { Image-change. } \\
\text { Acceptance of the existence of } \\
\text { human rights violations. } \\
\text { Seeks the acceptance of the } \\
\text { global community. }\end{array}$ & $\begin{array}{l}\text { Liberalism. } \\
\text { Neo-populism. } \\
\text { Democracy. }\end{array}$ & $\begin{array}{l}\text { Yes, but it was still } \\
\text { germinating } \\
\text { (developing). }\end{array}$ \\
\hline $\begin{array}{c}\text { Franco } \\
(1992-1994)\end{array}$ & $\begin{array}{l}\text { Image-change. } \\
\text { Acceptance of the existence of } \\
\text { human rights violations. } \\
\text { Acceptance by the global } \\
\text { community }\end{array}$ & $\begin{array}{l}\text { Liberalism. } \\
\text { President Franco's soft nationalism. } \\
\text { Democracy. }\end{array}$ & $\begin{array}{l}\text { Yes, but it was still } \\
\text { germinating } \\
\text { (developing). }\end{array}$ \\
\hline $\begin{array}{c}\text { Cardoso } \\
(1995-2002)\end{array}$ & $\begin{array}{l}\text { Image-consolidation. } \\
\text { Transparency and dialogue with } \\
\text { UN and OAS mechanisms. } \\
\text { Seeks the respect of the global } \\
\text { community. }\end{array}$ & $\begin{array}{l}\text { Neo-liberalism. } \\
\text { Democracy. }\end{array}$ & Yes (Advanced) \\
\hline $\begin{array}{c}\text { Lula } \\
(2003-2010)\end{array}$ & $\begin{array}{l}\text { Image-shift. } \\
\text { Transparency as well as dialogue } \\
\text { and compliance with some UN } \\
\text { and OAS mechanisms. } \\
\text { First attempts to exercise } \\
\text { leadership within the global } \\
\text { community by a Brazilian } \\
\text { President. }\end{array}$ & $\begin{array}{l}\text { Neo-liberalism, but with social } \\
\text { programmes directed to the poorer } \\
\text { part of the population; } \\
\text { Populism. } \\
\text { Democracy. }\end{array}$ & $\begin{array}{c}\text { Yes } \\
\text { (Consolidated) }\end{array}$ \\
\hline
\end{tabular}

As shown in table 1 , this shift in domestic politics and the subsequent change in public and private attitudes within the country had an impact also on Brazilian foreign policy. In fact, it seems that those initiatives which had been undertaken by the Cardoso Administrations in order to align their foreign policy with international human rights standards were advanced greatly by Lula Administrations, which, as a result, helped strengthen the country's "[...] legitimacy in the international arena and its authority as a rule-abiding player in global and regional political and economic structures [...]” (WHITEHEAD, 2001 apud MACAULAY, 2007, 28). ${ }^{57}$ The result was that Brazil, under Lula Administrations, opened itself for international scrutiny more than ever before in its history. This might indicate the country's conformity to the current world order through the process of acculturation ${ }^{58}$ as a strategy to secure its global acceptance and legitimacy (AMORIM, 2010). At this

\footnotetext{
${ }^{57}$ Macaulay analyses why the Cardoso Administrations were unable to tackle the continuing existence of human rights violations in its eight years of duration. It is accepted here that the same logic of analysis used by the author in regard to governmental efforts to solve the problem of persistent human rights violations could be applied to Lula Administrations as well. The difference here, however, is that Lula Administrations went further in relation to its foreign policy, precisely due to the fact they made Brazil seek the exercise of some kind of global leadership for the first time in its history.

58 'By acculturation, we mean the general process by which actors adopt the beliefs and behavioural patterns of the surrounding culture` in Goodman and Jinks $(2004,626)$.
} 
time, however, Brazil has positioned itself in a more strategic manner, demanding world recognition proportionate to its current economic ${ }^{59}$ and political growing powers (PINHEIRO, 1999). Perhaps for the first time in world history a Brazilian president has not only sought, but to some extent come to exercise international leadership. ${ }^{60}$ Further, as the "Lula Effect" ${ }^{11}$ boosted the confidence of Brazilians as much as that of the Brazilian State, this was reflected in both domestic and foreign policies undertaken by Brazil. As a consequence, one could affirm that Brazilian democratic institutions are stronger than ever before, particularly due to the fact that civil and political rights are being enjoyed to a great extent in Brazil nowadays. However, this does not at all mean that social injustice, poverty, urban and rural violence or, simply put, social authoritarianism has been resolved. In spite of all the advancements concerning civil and political rights that have occurred since its re-democratization, Brazil is yet to overcome the huge gap between the "haves" (a tiny portion of the population) and the "have-nots" (the sound majority of the population who are still lacking the conditions to fully enjoy their economic, social and cultural rights). ${ }^{62}$ For that reason structural changes are necessary in Brazil (PICQ 2004, 4; DAGNINO, 1998). This is exactly where the role played by human rights defenders becomes important and why the emphasis on their protection against state and non-state violence is crucial. Simply put: human rights defenders are the ones who organize and carry out fights for democracy and human rights in the country. ${ }^{63}$

The reconstruction of the politics of human rights conducted above has unveiled key (legal, political, economic, social, and cultural) elements regarding the discourses and practices of pivotal actors within the Brazilian context, that is, the post-1985 Brazilian presidents who, in a way or another, contributed to the development and establishment of a post-1985 governmental culture of human rights. ${ }^{64}$ It should be borne in

\footnotetext{
${ }^{59} \mathrm{Ibid}$ (n 14).

${ }^{60}$ The Iran Nuclear Programme issue, the G20 negotiations, the work within the BRICS are good examples of President Lula's attempts to exercise global leadership. Although in Brazilian recent history Cardoso was the first President to have effectively used 'presidential diplomacy' as a strategy for his foreign policy, he did not have the same impact as President Lula had in exercising some degree of global leadership by conducting the same strategy of 'presidential diplomacy'. See Vilela and Neiva (2011); Amorim (2010).

${ }^{61}$ The expression was originally coined to refer to economic (mostly argued as negative) effects of an eventual Lula's election as the first Brazilian President who did not come from any traditional elite group. As President Lula sought the exercise of some degree of global leadership in both economic and political matters, the expression started being used by both Brazilian and international mass media to refer also to his international increasing influence. The term is used here in the second manner, that is, to refer to the positive effects President Lula had on economic and political issues, both internally and abroad. For a comment on the origin of the use of the expression “Lula effect" see Flynn (2005). For an account of Lula Administration's policies see Paula (2011).

${ }^{62}$ During the two Lula Administrations and the first Rousseff Administration about 40 millions of people ascended from poverty or misery to low middle class in Brazil. Indicators can be found at the Brazilian Institute for Geography and Statistics (IBGE in Portuguese, http://www.ibge.gov.br/home/) and the Institute for Applied Economic Research (IPEA in Portuguese www.ipea.gov.br).

${ }^{63}$ 'It is unfortunate that in real terms neither the return to democracy and sound legal framework for the defence of human rights, nor the presence of an active and experienced civil society has provided sufficient protection to human rights defenders or their activities. In their efforts to attain social, economic, environmental and cultural rights; in seeking to expose human rights violations and to end impunity for these violations; and in resisting discrimination or marginalization, human rights defenders continue to be threatened and harmed" in Brazil. In UN (2006, Paragraph 14).

${ }^{64}$ An accurate summary of the aforementioned developments has been provided by Pinheiro, as follows: "Since 1985, the personal vol.09, no. 04, Rio de Janeiro, 2016.pp. 2263-2311 2276
} 
mind, however, that "while the various post-1985 democratic administrations have not deliberately perpetrated violence, they have demonstrated a marked inability to control it and singular incapacity to reduce criminal practices and guarantee social peace" (PINHEIRO, 1998, 2). ${ }^{65}$ This means that in spite of the various post-1985 administrations' efforts, the fact is that the necessary structural changes towards a new citizenship in Brazil are yet to come. ${ }^{66}$ In this regard, it seems imperative to ask: Why do we have this particular set of circumstances? Why haven't post-1985 democratic administrations been able to control violence and thwart human rights violations yet?

The issue relates to historical contradictions present in the collective and dialectical disputes existent among subjects (agents) from dominant and dominated sectors, and their respective structures, in the pursuit of economic, political and symbolic powers toward establishing hegemony. ${ }^{67}$ In general terms, however, the responsibility to tackle this apparent deadlock situation rests on both state ${ }^{68}$ and civil society, which are seen here as in continuity with one another (DAGNINO, 1998). Thus, one unresolved issue refers to the type of relationship Brazil has had with (national and transnational) civil society ${ }^{69}$ and the impact this relationship has had on the development of a governmental culture of human rights.

It seems appropriate, therefore, that this paper analyses the politics of human rights that led to the development of the aforementioned governmental culture of human rights (1964-2010) as well as to a shift in

convictions and intentions of each president have been decisive: José Sarney responded to pressure to distance himself from the legacy of the fallen authoritarian regime, but was unable to make a clear break with the past; Fernando Collor, coincidentally the first president in the American continent to be impeached, effectively implemented the policy shift which had been gaining momentum through the 1980s; Itamar Franco established a firm stance in opposition to the dictatorship and filled his government with officials dedicated to social struggle; and finally Fernando Henrique Cardoso expressed the intention of using his presidential authorities to consolidate human rights law despite resistance from the establishment", in Pinheiro $(1999,19)$. Although the author's analysis does not include the two Lula Administrations, it can be applied to them as well, for even though the structures that cause violence remained untouched, the governmental cultural of human rights was consolidated under the two Lula Administrations by any account.

${ }^{65}$ Here as well, although the author's analysis does not include the two Lula Administrations, it can be applied to them as well, for even though the historical structures that cause violence in Brazil remained untouched under the two Lula Administrations.

${ }^{66}$ Human rights violations and, particularly, state and non-state violence against activists and defenders of rights can be observed in all phases of Brazilian history, which make evident that the Brazilian formal and informal structures must be changed for better and toward a project for a new citizenship. For a detailed explanation of this project for a new citizenship see Alvarez et al (1998). The analysis conducted here focuses on the state and non-state violence against human rights defenders that have been persistent through authoritarianism, transition and democratic rule in Brazil. For a competent account of violence as a development concern see Moser and Mcllwaine (2006). For an account of the politics of human rights in Brazil and the country's necessity to overcome its pre-existing structures that thwart the realization of human rights see Picq (2004).

${ }^{67}$ The Gramscian concept of hegemony could be interpreted as "[...] a process of articulation of different interests around the gradual and always renewed implementation of a project for the transformation of society [...]” in Dagnino (1998, 37). See also Terto Neto (2010); Semeraro (1999); Simionatto (1995); Gramsci (2004); Bourdieu (1998; 1997; 1996).

${ }^{68}$ Under a gramscian perspective of an "amplified state", it is accepted here that the state composes itself of different camps such as the social, the economic, the political, the cultural, among others; and that once state retains the monopoly of legitimized physical and symbolic violence, it ends up regulating the functioning of those camps. In any case, the reconstruction of Brazilian social structures must involve all sectors of society (public and private, state and non-state) if it were ever to produce a fairer society as an ultimate outcome. See Semeraro (1999); Simionatto (1995); Gramsci (2004); Bourdieu (1998; 1997; 1996).

${ }^{69}$ As mentioned earlier, civil society as taken here as an arena of politics. For a detailed explanation of how the concept has vol.09, no. 04, Rio de Janeiro, 2016.pp. 2263-2311 2277 
post-1985 Brazilian human rights foreign policy. Both have occurred through the Brazilian transition to formal democracy and been highly influenced by national and transnational human rights advocacy networks. ${ }^{70}$ This social process has undoubtedly affected human rights discourses and practices within the country. As a result, it is generally accepted that the positivization ${ }^{71}$ and socialization ${ }^{72}$ of international human rights instruments have produced repercussions in Brazil's legal, political, economic, social and cultural reality, which have contributed not only to the development of a governmental culture of human rights and the surge of a more ambitious human rights foreign policy, but also, and perhaps more importantly, to the facing-up of social authoritarianism in Brazil. It was within this context that the creation of the PPDDH occurred. Applying the CDA approach, the next section will make an attempt to identify some of the contradictions between Brazil's practices and human rights rhetoric in the hope of unveiling the possible reasons for the occurrence of such a phenomenon (PPDDH's establishment).

\section{THE PPDDH'S CREATION IN THE CONTEXT OF THE AFORESAID CHANGES}

It seems evident, therefore, that the received story ${ }^{73}$ which has been reconstructed in the previous section indicates the existence of the umbilical connections among re-democratization, institutionalization of international and regional norms and the governmental culture of human rights in Brazil's recent history. In fact, it seems to be the case that democracy and human rights work together in order to bring socio-economic, political, cultural and particularly legal developments within Brazil.

This way, along the process of democratization, Brazil has adhered to important international human rights instruments, accepting expressly the legitimacy of international preoccupations and opening itself to dialogue with international instances concerning the fulfilment of the country's international obligations. In the

developed, particularly in Latin America see Avritzer (2006).

70 "Networks are forms of organization characterized by voluntary, reciprocal, and horizontal patterns of communication and exchange. $[\ldots]$ In spite of the differences between domestic and international realms, the network concept travels well because it stresses fluid and open relations among committed and knowledgeable actors working in specialized issue areas. We call them advocacy networks because advocates plead the causes of others or defend a cause or proposition. Advocacy captures what is unique about these transnational networks: they are organized to promote causes, principled ideas, and norms, and they often involve individuals advocating policy changes that cannot be easily linked to a rationalistic understanding of their 'interests'." In Keck and Sikkink (1998, 8-9). Although Keck and Sikkink note that Transnational Advocacy Network might include agents, entities, organs and structures from both public and private sectors, they warn their research does not lead to believe these interactions characterize the formation of an emerging global civil society. Instead, they prefer to work with the conception of transnational civil society as a dialectical and fragmented space of social, economic and political struggles in which specific groups may surge and be legitimized. I have considered their approach toward the category transnational civil society, which has been contrasted with the national civil society one for clarity purposes.

${ }^{71}$ Positivization is a legal-formal procedure through which international norms are implemented into national juridical systems; whereas, socialization would be a socio-political process through which international human rights norms are socialized within national States. See Risse and Sikkink (1999); Mendes et al (2008); Risse, Ropp, and Sikkink (2013).

${ }^{72}$ Ibid.

${ }^{73}$ The received story is taken here as composed by oral history and doctrinal texts of the history of Brazil. As for the purposes of this paper, only the latter has been utilized for the reconstruction of the politics of human rights in Brazil. 
process of democratization, on the other hand, the participation and mobilization of civil society and NGOs in the debate on the protection of human rights were accentuated.

It is within this scenario that the human rights thematic starts to consolidate itself as one of the most relevant items in the agenda of contemporaneous Brazil. (PIOVESAN, 2008, 276)

Since the transition from authoritarianism to formal democracy, the institutionalization of international and regional human rights law has increased significantly in Brazil. With the promulgation of the 1988 Brazilian Constitution a constitutionally legitimised legal system was restored and, since then, it has developed itself in order to find a balance with international and regional human rights normative. ${ }^{74}$ Today there is a well-structured legal framework designed to guarantee (at least formally) the full enjoyment of fundamental rights by anyone in Brazil. Table 2 describes the development of the Brazilian legal framework for the protection of human rights in relation to the reception of core international and regional human rights instruments into Brazil's legal system. ${ }^{75}$

\section{Table 2 - Brazil's Legal Framework for the Protection of Human Rights and the Reception of International and Regional Human Rights Instruments by its Legal System, from 1964}

to 2010

\begin{tabular}{|c|c|c|c|}
\hline Government & UN HR Instruments & OAS HR Instruments & Brazilian Law \\
\hline $\begin{array}{c}\text { Military } \\
\text { Regime } \\
\text { (31 Mar } \\
\text { 1964-15 Mar } \\
\text { 1985) }\end{array}$ & $\begin{array}{l}\text { International Convention on the } \\
\text { Elimination of All Forms of } \\
\text { Racial Discrimination (CERD); } \\
\text { Convention on the Elimination } \\
\text { of All Forms of Discrimination } \\
\text { against Women (CEDAW) }\end{array}$ & & $\begin{array}{l}1967 \text { Federal } \\
\text { Constitution; } 1969 \\
\text { Constitutional } \\
\text { Amendment number } 1 \\
\text { to the } 1967 \text { Federal } \\
\text { Constitution; Infra- } \\
\text { constitutional law, such } \\
\text { as Indigenous Peoples } \\
\text { Statute(Lei n. 6.001 of } \\
\text { 01 October 2003). }\end{array}$ \\
\hline $\begin{array}{l}\text { Sarney } \\
(21\end{array}$ & $\begin{array}{l}\text { Convention against Torture and } \\
\text { Other Cruel, Inhuman or }\end{array}$ & $\begin{array}{l}\text { Inter-American Convention to } \\
\text { Prevent and Punish Torture }\end{array}$ & $\begin{array}{c}1969 \text { Federal } \\
\text { Constitution; } 1988 \\
\text { Federal Constitution; } \\
\text { Infra-constitutional law, }\end{array}$ \\
\hline
\end{tabular}

\footnotetext{
${ }^{74}$ See particularly Article 5, Paragraphs 1-4 of the 1988 Brazilian Constitution. Paragraphs 3 and 4 were added by the Constitutional Amendment number 45, Dec. 8th 2004. Its full text in English can be found at: <http://www.vbrazil.com/government/laws/titleII.html> accessed 20 July 2016.

75 To organize the table I drew on the following sources: Piovesan (2008); Pinheiro (1998 and 1999); Alves (2011); Bittar and Almeida (2010); Mendes et al (2008); UN (http://ww.un.org) and OAS (http://www.oas.org) websites. The analysis considers the relationship between democratization and human rights. Therefore, timeframe has been limited to the Brazilian transition from authoritarianism to formal democracy (1964 until 2010). Nevertheless, it should be stressed that Brazil is part of other international and regional human rights instruments signed and ratified prior to 1964. At the UN level there is the Convention on the Prevention and Punishment of the Crime of Genocide (signed on 11 December 1948 and ratified on 15 April 1952). At the OAS level there are: Inter-American Convention on Granting of Civil Rights to Women (signed on 02 May 1948 and ratified on 29 January 1952); and Inter-American Convention on the Granting of Political Rights to Women (signed on 02 May 1948 and ratified on 15 February 1950).
} 


\begin{tabular}{|c|c|c|c|}
\hline $\begin{array}{l}\text { Apr1985-15 } \\
\text { Mar 1990) }\end{array}$ & $\begin{array}{l}\text { Degrading Treatment or } \\
\text { Punishment (CAT) }\end{array}$ & (ICPPT) & $\begin{array}{c}\text { such as Public Civil } \\
\text { Action Law (Lei n. } 7.347 \\
\text { of } 24 \text { July 1985); } \\
\text { Universal Access to } \\
\text { People with Deficiency } \\
\text { to Services Law (Lei n. } \\
7.405 \text { of } 12 \text { November } \\
\text { 1985); and People with } \\
\text { Deficiency Law (Lei n. } \\
\text { 7.853 of 24 October } \\
\text { 1989). }\end{array}$ \\
\hline $\begin{array}{l}\text { Collor } \\
(15 \text { Mar } \\
1990-29 \\
\text { Dec 1992) }\end{array}$ & $\begin{array}{l}\text { Convention on the Rights of the } \\
\text { Child (CRC); International } \\
\text { Convention on Civil and } \\
\text { Political Rights (CCPR); } \\
\text { International Convention on } \\
\text { Economic, Social and Cultural } \\
\text { Rights (CESCR) }\end{array}$ & $\begin{array}{c}\text { American Convention on } \\
\text { Human Rights "Pact of San Jose, } \\
\text { Costa Rica" (ACHR) }\end{array}$ & $\begin{array}{c}1988 \text { Federal } \\
\text { Constitution; Infra- } \\
\text { constitutional law, such } \\
\text { as Child and Adolescent } \\
\text { Statute (Lei n. } 8.069 \text { of } \\
\text { 13 July 1990); and } \\
\text { Promotion, Protection } \\
\text { and Recuperation of } \\
\text { Health Law (Lei n. } \\
\text { 8.080 of 19 September } \\
\text { 1990). }\end{array}$ \\
\hline $\begin{array}{c}\text { Franco } \\
\text { (29 Dec } \\
\text { 1992-31 Dec } \\
\text { 1994) }\end{array}$ & & & $\begin{array}{l}1988 \text { Federal } \\
\text { Constitution; Infra- } \\
\text { constitutional law. } \\
\text { Note: It could not be } \\
\text { found any important } \\
\text { passing of federal law in } \\
\text { regard to human rights } \\
\text { matters during the } \\
\text { Franco Administration. } \\
\text { However, all federal laws } \\
\text { passed in previous } \\
\text { administrations and that } \\
\text { were already in force } \\
\text { could be used to } \\
\text { advance fundamental } \\
\text { rights in the country. }\end{array}$ \\
\hline $\begin{array}{l}\text { Cardoso } \\
(1 \text { Jan } 1995- \\
31 \text { Dec } \\
2002)\end{array}$ & $\begin{array}{l}\text { Optional Protocol to the } \\
\text { Convention on the Elimination } \\
\text { Discrimination against Women } \\
\text { (CEDAW-OPT) }\end{array}$ & $\begin{array}{l}\text { Inter-American Convention on } \\
\text { the Prevention, Punishment and } \\
\text { Eradication of Violence against } \\
\text { Women "Convention of Belem } \\
\text { do Para" (ICPPEVAW); } \\
\text { Additional Protocol to the } \\
\text { American Convention on } \\
\text { Human Rights in the Area of } \\
\text { Economic, Social and Economic } \\
\text { Rights "Protocol of San Salvador" } \\
\text { (AP-ACHR-ESCR); Protocol to }\end{array}$ & $\begin{array}{c}1988 \text { Federal } \\
\text { Constitution; Infra- } \\
\text { constitutional law, such } \\
\text { as Environmental } \\
\text { Crimes Law (Lei n. } \\
\text { 9.605 of } 12 \text { February } \\
\text { 1998); Guidelines and } \\
\text { Bases for Education Law } \\
\text { (Lei n. 9.394 of 20 } \\
\text { December 1996); }\end{array}$ \\
\hline
\end{tabular}




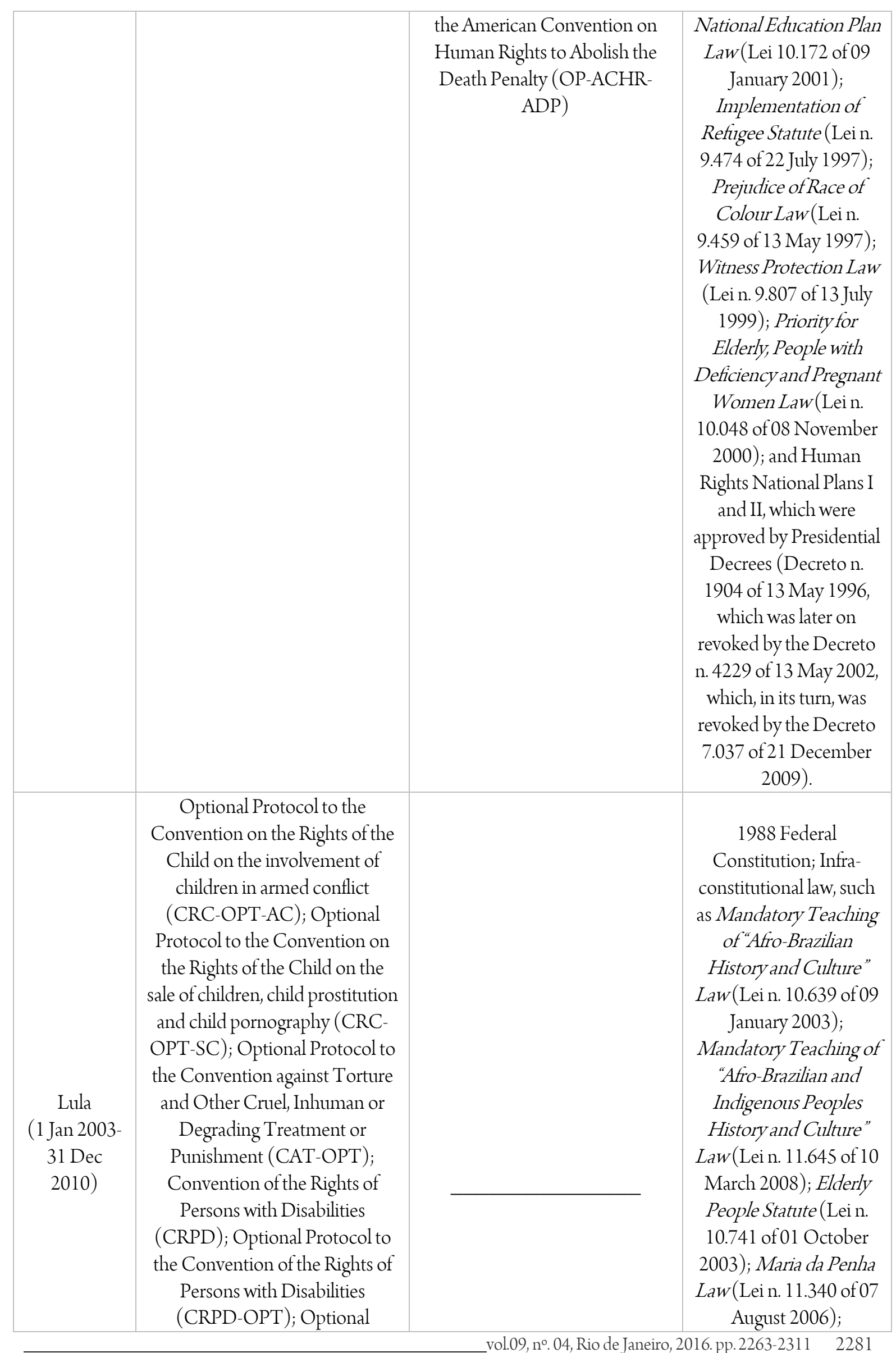




\begin{tabular}{|c|c|c|}
\hline Protocol to the International & Protection to \\
Convention on Civil and & Quilombola People Law \\
Political Rights (CCPR-OPT1); & (Decreto n. 4.887 of 20 \\
Optional Protocol to the & November 2003); \\
International Convention on & Human Rights National \\
Economic, Social and Cultural & Plan III, which was \\
Rights (CCPR-OPT2); & approved by a \\
International Convention for the & Presidential Decree \\
Protection of All Persons from & (Decreto 7.037 of 21 \\
Enforced Disappearance & December 2009, which \\
(CPED) & revoked the Decreto n. \\
& 1904 of 13 May 1996 \\
& (Human Rights \\
& & National Plan I) and the \\
& Decreto n. 4229 of 13 \\
& May 2002 (Human \\
& & Rights National Plan II); \\
& and the National Policy \\
& for the Protection of \\
& & Human Rights \\
& & Defenders (Decreto \\
& & 6.044 of 12 February \\
& & 2007). \\
\hline
\end{tabular}

In spite of the perceived political, economic, social and cultural advancements, it is not always the case that the received story is capable of identifying trades and causal factors within a set of circumstances that originate social change as it has recently occurred. As a result, it is important to compare the received story with other relevant narratives. In this respect, as for what refers to this paper, a taxonomy concerning the reception of international and regional human rights instruments into Brazil's legal system is going to be conducted below. The goal is to provide (sketch) a framework capable of unveiling trades, causal factors, contradictions, and potential ambiguities that will be helpful for the comparison between the received story and Brazil's practices and human rights rhetoric to be effective. Furthermore, later on in this section documents on human rights and on foreign policy produced by Brazil will be analysed under the CDA approach in order for a deeper analysis of the phenomenon to be conducted. It is this deeper analysis (another relevant narrative) that will be confronted to the received story given in the previous section. It is expected that this critical narrative (deeper analysis) will indicate the possible causal chains that led to the creation in 2004 of the PPDDH by the Brazilian federal government.

\section{Taxonomy of International and Regional Human Rights Instruments Adopted by Brazil}

In order to critically approach the creation of the PPDDH as part of a context related to the aforementioned changes that were presented in the previous sections, the paper draws on Nancy Fraser's two- 
dimensional conception of justice, which is based on the redistribution and recognition paradigms as being capable of taking "account of the complexity of contemporary politics by treating redistribution and recognition as dimensions of justice that can cut across all social movements" (FRASER, 1999, 27; marks from the original) and whose normative core is, as she argues, the "notion of parity of participation" (FRASER, 1999, 37). Further, explaining that those two paradigms can be contrasted in the way they understand the concept of injustice, the form of remedy they suggest for injustice, the manner they conceive the groups victimized by injustice, and how they perceive the group differences (FRASER, 1999); Nancy Fraser argues, nevertheless, that any assumption of the redistribution and recognition paradigms as denying their interconnectedness should be avoided, especially due to the fact that, as she argues, the objective "should be, rather, to develop an integrated approach that can encompass, and harmonize, both dimensions of social justice" (FRASER, 1999, 33). Also helpful to the analysis conducted here is her perspectival dualism of redistribution and recognition concept, for "perspectival dualism in social theory complements participatory parity in moral theory" (FRASER, 1999, 48). In short, as well put by Ajay Gudavarthy, "such a critical analysis $[\ldots]$ is possible with the interpretation of culture, politics and economy as three different but closely interrelated dimensions of domination and exclusion” (GUDAVARTHY, 2012, 10). The perception of their interconnectedness is, therefore, pivotal for comprehending the trades, causal factors, contradictions, and ambiguities that might explain the PPDDH's origins within the Brazilian society.

It should be borne in mind, nevertheless, that departing from Nancy Fraser's tripartite approach the paper goes one step further concerning the contextual analysis of the creation of the PPDDH, that is, it adds to the equation the social dimension. As a result, it is important to consider that this study proposes the use of a tetrapartite approach and, consequently, it is going to conduct a critical analysis of the aforementioned phenomenon taking into account not only the political, economic, and cultural dimensions, but also the social dimension, expecting to contribute, thus, to the advancement of the existing literature. ${ }^{76}$

Referring to the taxonomy of international and regional human rights instruments that have been either ratified or acceded by Brazil from 1964 to 2010, it should be noted that the counting of these human rights instruments has been conducted here considering the type of rights contained in each of the human rights instruments analysed, instead of focusing solely on considering the general subject presented in the instrument's title. For instance, despite the ICPPEVAW refers to "violence against women" as a general subject contained in its title, it is possible to identify references to types of rights such as civil, political, economic, social and cultural ones within the document itself. In other words, although the general subject refers to a specific topic, as exposed in the title of the document, within each instrument respectively it is possible to locate specific references to types of

\footnotetext{
${ }^{76}$ It is still possible the appliance of a fifth dimension, the symbolic one, making possible the expansion of the critical analysis to a pentapartite approach. The analysis of this symbolic dimension would have to be based on the oral history, usually collected via interviews with human rights defenders, state representatives and other agents in regard to their perceptions on human rights, vol.09, nº. 04, Rio de Janeiro, 2016.pp. 2263-2311 2283
} 
human rights which are not necessarily given (shown) by the presented general subject found in the document's title. Tables 3 and 4 clarify this as well as describe the UN and OAS human rights instruments that have been ratified by Brazil per general subject and type of rights from 1964 to 2010 respectively. ${ }^{77}$

Table 3 - UN HR Instruments Ratified/Acceded by Brazil, per Subject and Type of Rights, from 1964 to 2010

\begin{tabular}{|c|c|c|}
\hline HR Instrument & Subject & Type of Right (s) \\
\hline CERD & Racial discrimination & Cultural rights \\
\hline CEDAW & Discrimination against women & Civil, political, economic, social, and cultural rights \\
\hline CAT & Torture & Civil rights \\
\hline CRC & Child & Civil, economic, social, and cultural rights \\
\hline CCPR & Civil and political rights & Civil and political rights \\
\hline CESCR & Economic, social, and cultural rights & Economic, social, and cultural rights \\
\hline CEDAW-OPT & Discrimination against women & Civil, political, economic, social, and cultural rights \\
\hline CRC-OPT-AC & Child & Civil, economic, social, and cultural rights \\
\hline CRC-OPT-SC & Child & Civil, economic, social, and cultural rights \\
\hline CAT-OPT & Torture & Civil rights \\
\hline CRPD & Persons with disabilities & Civil, political, economic, social, and cultural rights \\
\hline CRPD-OPT & Persons with disabilities & Civil, political, economic, social, and cultural rights \\
\hline CCPR-OPT1 & Civil and political rights & Civil and political rights \\
\hline CCPR-OPT2 & Abolition of death penalty & Civil and political rights \\
\hline CPED & Enforced disappearance & Civil rights \\
\hline
\end{tabular}

Table 4 - OAS HR Instruments Ratified/Acceded by Brazil, per Subject and Type of Rights, from 1964 to 2010

\begin{tabular}{|c|c|c|}
\hline $\begin{array}{c}\text { HR Instrument } \\
\text { ICPPT }\end{array}$ & Subject & Type of Right \\
\hline ACHR & Corture & Civil rights \\
\hline $\begin{array}{c}\text { ICPPEVAW } \\
\text { AP-ACHR- } \\
\text { ESCR }\end{array}$ & Violence against women & Civil, political, economic, social, and cultural rights \\
\hline OP-ACHR-ADP & Civil, political, economic, social, and cultural rights \\
\hline
\end{tabular}

As made evident by tables 3 and 4 , it can be seen, on the one hand, that the general subjects which are indicated by the titles of the UN and OAS human rights instruments being analysed here have been identified as racial discrimination; discrimination against women; torture; child; civil and political rights; economic, social and cultural rights; persons with disabilities; abolition of death penalty; and enforced disappearance; whereas, on the

human rights defenders, social justice etc. For an excellent analysis that includes the fifth dimension see Terto Neto (2016 a).

${ }^{77}$ I organised the tables drawing my interpretations from the analysis of each one of the international and regional human rights instruments ratified or acceded by Brazil. The United Nations <www.un.org > accessed 20 October 2016, and The Organization of American States <www.oas.org > accessed 20 October 2016. 
other hand, the analysis of the same UN and OAS human rights instruments led to the identification of types of rights referred to in the texts of each analysed document as civil; political; economic; social; or cultural rights. The deeper analysis conducted in tables 5 and $6,{ }^{78}$ which describe the UN and OAS human rights instruments ratified or acceded by Brazilian governments per general subject and type of rights from 1964 to 2010 respectively, helps to unfold the apparent priority (or its absence) given by each Brazilian government in regard to human rights issues. This is crucial for the identification of political, economic, cultural, and social trades, causal chains, and ambiguities related to human rights issues during the authoritarianism, transition to democracy, and formal democracy phases in Brazil's recent history.

\section{Table 5 - Brazilian Administrations and UN HR Instruments per Subject and Type of} Rights, from 1964 to 2010

\begin{tabular}{|c|c|c|c|}
\hline Administration & $\begin{array}{c}\mathrm{HR} \\
\text { Instrument }\end{array}$ & General Subject & Type of Right (s) \\
\hline \multirow[b]{2}{*}{$\begin{array}{l}\text { Military Regime } \\
(1964-1985)\end{array}$} & CERD & Racial discrimination & Cultural rights \\
\hline & CEDAW & $\begin{array}{l}\text { Discrimination against } \\
\text { women }\end{array}$ & $\begin{array}{l}\text { Civil, political, economic, social, and } \\
\text { cultural rights }\end{array}$ \\
\hline $\begin{array}{l}\text { Sarney }(1985- \\
1990)\end{array}$ & CAT & Torture & Civil rights \\
\hline \multirow{3}{*}{$\begin{array}{c}\text { Collor } \\
(1990-1992)\end{array}$} & CRC & Child & $\begin{array}{l}\text { Civil, economic, social, and cultural } \\
\text { rights }\end{array}$ \\
\hline & CCPR & Civil and political rights & Civil and political rights \\
\hline & CESCR & $\begin{array}{l}\text { Economic, social, and cultural } \\
\text { rights }\end{array}$ & Economic, social, and cultural rights \\
\hline $\begin{array}{c}\text { Franco }(1992- \\
1994)\end{array}$ & - & - & - \\
\hline $\begin{array}{l}\text { Cardoso (1995- } \\
\text { 2002) }\end{array}$ & $\begin{array}{l}\text { CEDAW- } \\
\text { OPT }\end{array}$ & $\begin{array}{l}\text { Discrimination against } \\
\text { women }\end{array}$ & $\begin{array}{l}\text { Civil, political, economic, social, and } \\
\text { cultural rights }\end{array}$ \\
\hline \multirow{8}{*}{$\begin{array}{c}\text { Lula } \\
(2003-2010)\end{array}$} & $\begin{array}{l}\text { CRC-OPT- } \\
\text { AC }\end{array}$ & Child & $\begin{array}{l}\text { Civil, economic, social, and cultural } \\
\text { rights }\end{array}$ \\
\hline & $\begin{array}{l}\text { CRC-OPT- } \\
\quad \text { SC }\end{array}$ & Child & $\begin{array}{l}\text { Civil, economic, social, and cultural } \\
\text { rights }\end{array}$ \\
\hline & CAT-OPT & Torture & Civil rights \\
\hline & CRPD & Persons with disabilities & $\begin{array}{l}\text { Civil, political, economic, social, and } \\
\text { cultural rights }\end{array}$ \\
\hline & CRPD-OPT & Persons with disabilities & $\begin{array}{l}\text { Civil, political, economic, social, and } \\
\text { cultural rights }\end{array}$ \\
\hline & CCPR-OPT1 & Civil and political rights & Civil and political rights \\
\hline & CCPR-OPT2 & Abolition to death penalty & Civil and political rights \\
\hline & CPED & Enforced disappearance & Civil rights \\
\hline
\end{tabular}

${ }^{78}$ Ibid. 
Table 6 - Brazilian Administrations and OAS HR Instruments per Subject and Type of Rights, from 1964 to 2010

\begin{tabular}{|c|c|c|c|}
\hline Administration & HR Instrument & General Subject & Type of Right (s) \\
\hline $\begin{array}{c}\text { Military Regime (1964- } \\
\text { 1985) }\end{array}$ & - & - & - \\
\hline Sarney (1985-1990) & ICPPT & Torture & Civil rights \\
\hline Collor (1990-1992) & ACHR & Human rights & $\begin{array}{l}\text { Civil, political, economic, social, and } \\
\text { cultural rights }\end{array}$ \\
\hline Franco (1992-1994) & - & - & - \\
\hline \multirow{3}{*}{$\begin{array}{c}\text { Cardoso } \\
(1995-2002)\end{array}$} & ICPPEVAW & Violence against women & $\begin{array}{l}\text { Civil, political, economic, social, and } \\
\text { cultural rights }\end{array}$ \\
\hline & $\begin{array}{l}\text { AP-ACHR- } \\
\text { ESCR }\end{array}$ & $\begin{array}{l}\text { Economic, social, and } \\
\text { cultural rights }\end{array}$ & Economic, social, and cultural rights \\
\hline & $\begin{array}{l}\text { OP-ACHR- } \\
\text { ADP }\end{array}$ & Abolition of death penalty & Civil and political rights \\
\hline Lula $(2003-2010)$ & - & - & - \\
\hline
\end{tabular}

As shown by tables 5 and 6, the military governments (1964-1985) ratified only two UN human rights instruments whose general subjects are racial discrimination (CERD) and discrimination against women (CEDAW); and types of rights are cultural rights (CERD), and civil, political, economic, social and cultural rights (CEDAW) respectively. On the other hand, the post-1985 democratic governments ratified or acceded UN and OAS human rights instruments whose general subjects are human rights (ACHR), torture (CAT, CAT-OPT, and ICPPT), child (CRC, CRC-OPT-AC, and CRC-OPT-SC), civil and political rights (CCPR and CCPROPT1), discrimination against women (CEDAW-OPT and ICPPEVAW) economic, social and cultural rights (CESCR and AP-ACHR-ESCR), persons with disabilities (CRPD and CRPD-OPT), abolition of death penalty (CCPR-OPT2 and OP-ACHR-ADP), and enforced disappearance (CPED); and types of rights are cultural rights (CERD), civil rights (CAT, CAT-OPT, and CPED), civil and political rights (CCPR, CCPR-OPT1, and CCPR-OPT2), civil, economic, social, and cultural (CRC, CRC-OPT-AC, and CRC-OPT-SC), economic, social, and cultural (CESCR), civil, political, economic, social, and cultural rights (CEDAW, CEDAW-OPT, CRPD, and CRPD-OPT) respectively.

Another important aspect of the taxonomy of UN and OAS human rights instruments ratified or acceded by Brazil per type of government (authoritarian, transitional, and democratic), general subject (racial discrimination, discrimination against women, torture, child, civil and political rights, economic, social and cultural rights, persons with disabilities, and abolition of death penalty) and type of rights (civil, political, economic, social, and cultural) from 1964 to 2010 respectively is that it can be related to the contextual analysis within the political, economic, cultural and social dimensions regarding the trades, causal chains, and ambiguities that are not only related to human rights issues during authoritarianism, transition to democracy, and formal democracy phases in vol.09, nº. 04, Rio de Janeiro, 2016.pp. 2263-2311 2286 
Brazil's recent history, but also able to unveil the reasons that made Brazil create the PPDDH with its particular configurations in 2004. In this regard, table $7^{79}$ describes the strong relationship between democracy and human rights as well as the inferred and apparently progressive impact by the re-democratization of the country (from authoritarianism to formal democracy) upon Brazilian post-1985 democratic governments' practices concerning domestic and foreign policies related to human rights affairs.

Table 7 - Human Rights Policies and Brazilian Administrations, from 1964 to 2010

\begin{tabular}{|c|c|c|c|}
\hline \multicolumn{2}{|c|}{ History } & Human Rights Domestic & Human Rights Foreign Policy \\
\hline Government & $\begin{array}{c}\text { Military Regime } \\
(1964-1985)\end{array}$ & None & $\begin{array}{c}\text { Denial of the existence of human rights } \\
\text { violations in Brazil }\end{array}$ \\
\hline Transition & $\begin{array}{c}\text { Sarney }(1985- \\
1990)\end{array}$ & $\begin{array}{l}\text { None, but human rights } \\
\text { rhetoric already existed. }\end{array}$ & $\begin{array}{l}\text { Image-change. } \\
\text { Acceptance of the existence of human right } \\
\text { violations in Brazil. } \\
\text { Seeks acceptance of the global community. }\end{array}$ \\
\hline \multirow{4}{*}{$\begin{array}{c}\text { Formal } \\
\text { Democracy }\end{array}$} & $\begin{array}{l}\text { Collor (1990- } \\
\text { 1992) }\end{array}$ & Yes, but it was germinating. & $\begin{array}{l}\text { Image-change. } \\
\text { Acceptance of the existence of human right } \\
\text { violations in Brazil. } \\
\text { Acceptance of the global community. }\end{array}$ \\
\hline & $\begin{array}{c}\text { Franco }(1992- \\
1994)\end{array}$ & $\begin{array}{l}\text { Yes, but it was still } \\
\text { germinating }\end{array}$ & $\begin{array}{l}\text { Image-change. } \\
\text { Acceptance of the existence of human right } \\
\text { violations in Brazil. } \\
\text { Acceptance of the global community. }\end{array}$ \\
\hline & $\begin{array}{l}\text { Cardoso (1995- } \\
\text { 2002) }\end{array}$ & Yes (Advanced) & $\begin{array}{l}\text { Image-consolidation. } \\
\text { Transparency and dialogue with UN and } \\
\text { OAS mechanisms. } \\
\text { Seeks respect of the global community. }\end{array}$ \\
\hline & $\begin{array}{l}\text { Lula (2003- } \\
\text { 2010) }\end{array}$ & Yes (Advanced) & $\begin{array}{l}\text { Image-consolidation. } \\
\text { Transparency, dialogue and compliance with } \\
\text { UN and OAS mechanisms. } \\
\text { First attempts to exercise leadership within the } \\
\text { global community by a Brazilian President. }\end{array}$ \\
\hline
\end{tabular}

As discussed earlier (see tables 1 and 2, in the end of this paper) and described also by the table 7 above, there are umbilical connections among re-democratization, institutionalization of UN and OAS instruments, and the surge and development of a governmental culture of human rights in Brazil's recent history. Moreover, based on the contents of the tables 3, 4, 5 and $6 \mathrm{I}$ have not only tracked the number of UN and OAS human rights 
instruments ratified or acceded by Brazilian Administrations, from 1964 to 2010, but also analyzed their contents in detail regarding the types of rights to which their texts refer. Adding the analysis contained in all presented tables, it is important to consider that the task now is to make connections among Brazilian Administrations (dimension 1), human rights policies or strategies (dimension 2), and human rights ratification or accession (dimension 3). As described by the tables (particularly table 2) above, from $1985^{80}$ until 2010 the Brazilian legal framework for the promotion and protection of human rights has developed with the reception of core international and regional human rights instruments into the Brazilian legal system, as follows: Sarney Administration ( 1 from UN and 1 from OAS), Collor Administration (3 from UN and 1 from OAS), Franco Administration (none), Cardoso Administrations (1 from UN and 3 from OAS), and Lula Administrations (8 from UN and none from OAS). Figures 1-3 help visualize this phenomenon better. They describe an increase since 1989 in the institutionalization of UN and OAS Human Rights Instruments by Brazil in light of the strengthening of Brazilian democratic institutions.

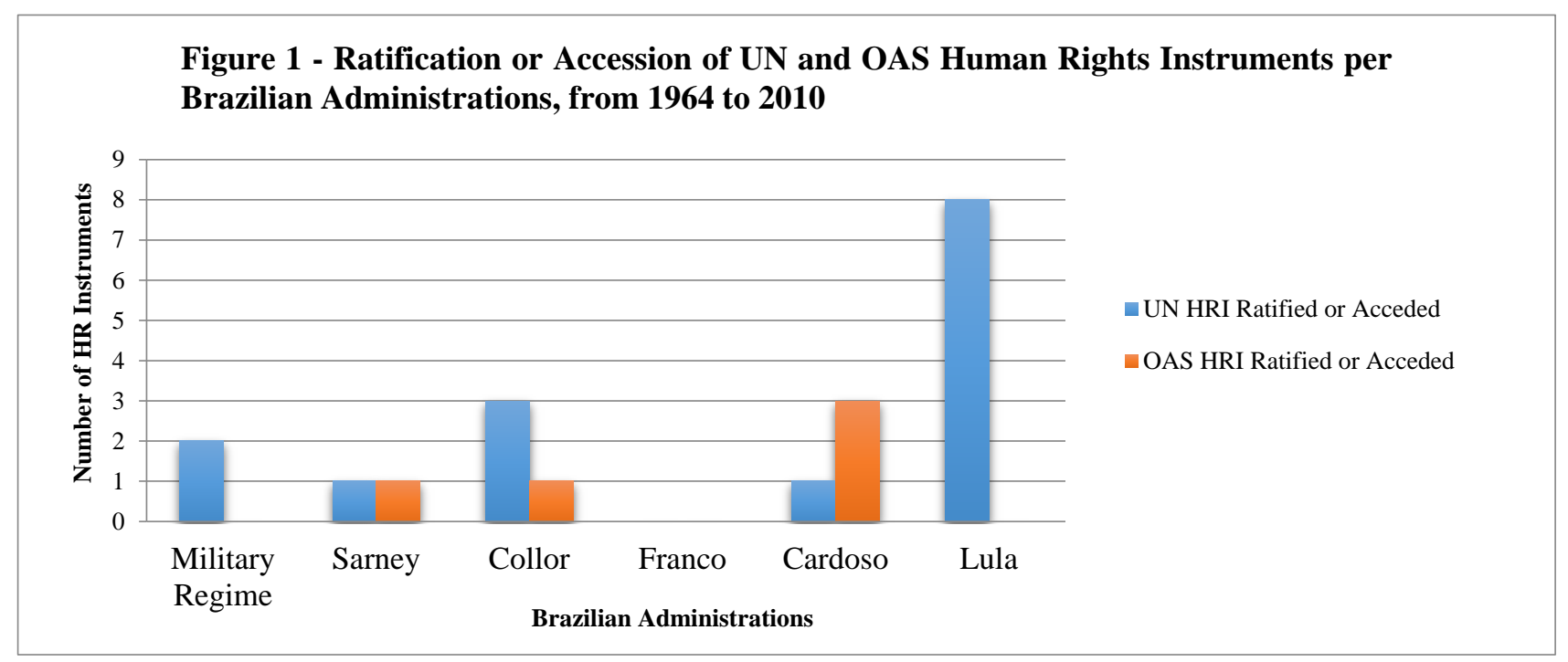

Source: The United Nations (www.un.org) and the Organisation of American States (www.oas.org)

\footnotetext{
${ }^{80}$ Given the umbilical connections among democracy (democratization), institutionalization of human rights and the governmental culture of human rights, it is accepted here that neither CERD nor CEDAW can be considered as taking part of a democratic process of institutionalization of human rights norms, for both were signed and ratified during the Military Regime in Brazil. Piovesan in regard to CERD defends this understanding. In regard to CEDAW, however, the author considers it to be the initial mark for the institutionalization of human rights process in Brazil. See Piovesan (2008).
} 


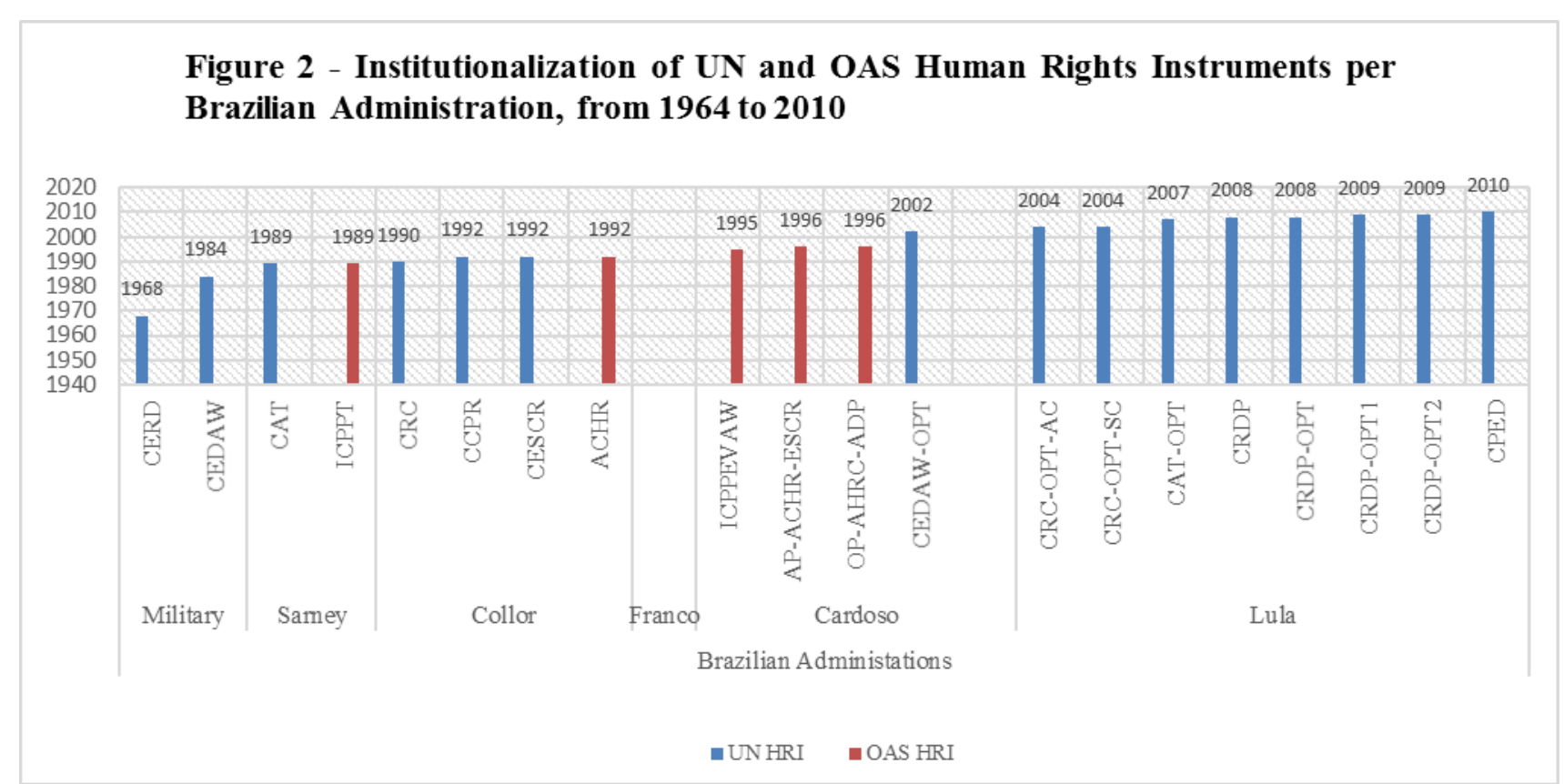

Source: The United Nations (www.un.org) and the Organisation of American States (www.oas.org)

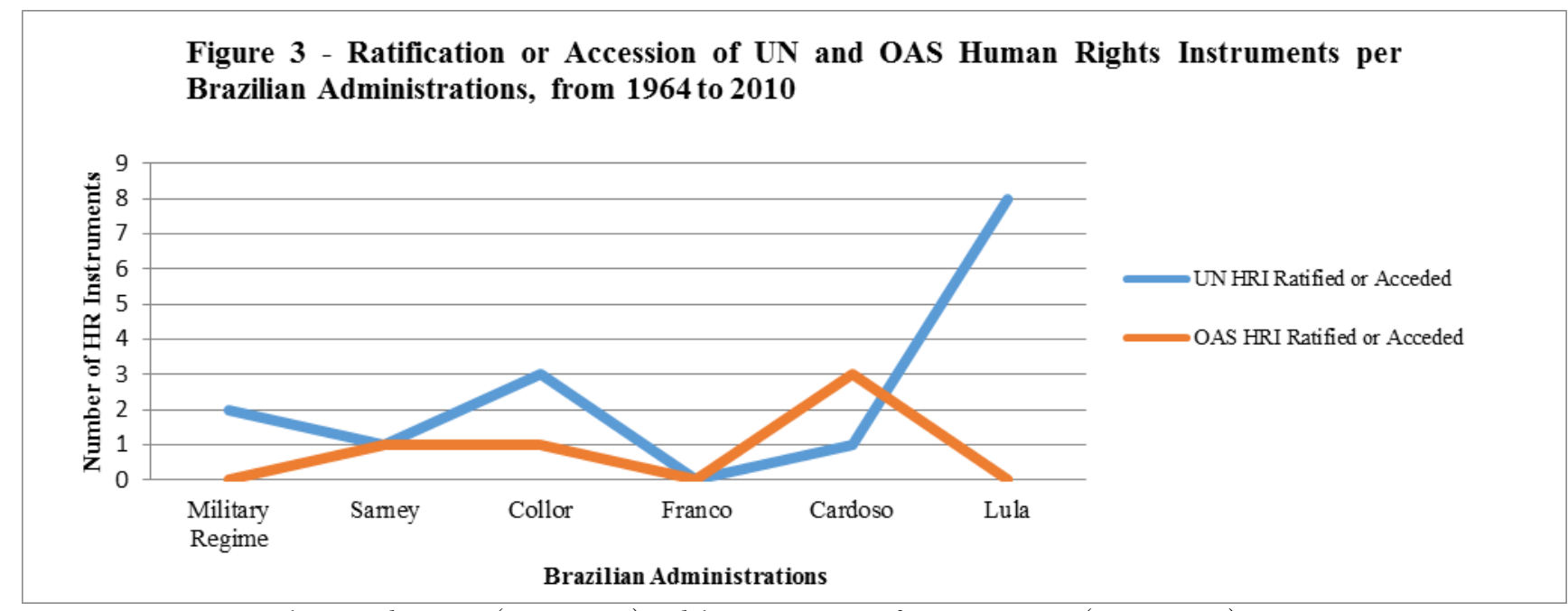

Source: The United Nations (www.un.org) and the Organisation of American States (www.oas.org)

From the analysis of figures 1-3 one can observe, for instance, the strong emphasis put by the two Lula Administrations on the institutionalization of UN human rights instruments into Brazil's legal system, whereas, during the same period, no OAS human rights instrument was internalized at all. This is certainly an indication that the Lula Administrations directed its human rights foreign policy ${ }^{81}$ to the $\mathrm{UN}$ more than to the OAS, despite the fact that President Lula sought to exercise leadership in South American regional economy and politics as well (SARAIVA, 2010).

\footnotetext{
81 "Brazil's commitment to the promotion of human rights is unwavering both within our borders and on a global scale. Brazil sees human rights being profoundly related to democracy, peace and development. The promotion of human rights is at the heart of Brazilian foreign policy, as illustrated by our attitude of solidarity and non-indifference toward many of the most vulnerable peoples on the planet" in Amorim (2010, 238).
} 
Having in mind that the task is to make connections among Brazilian Administrations (dimension 1), human rights policies or strategies (dimension 2), and human rights ratification or accession (dimension 3), now the more detailed analysis by table 5 above should be combined with those of figure 4 , which describe the general picture of UN and OAS human rights instruments per type of rights (civil, political, economic, social and cultural) ${ }^{82}$

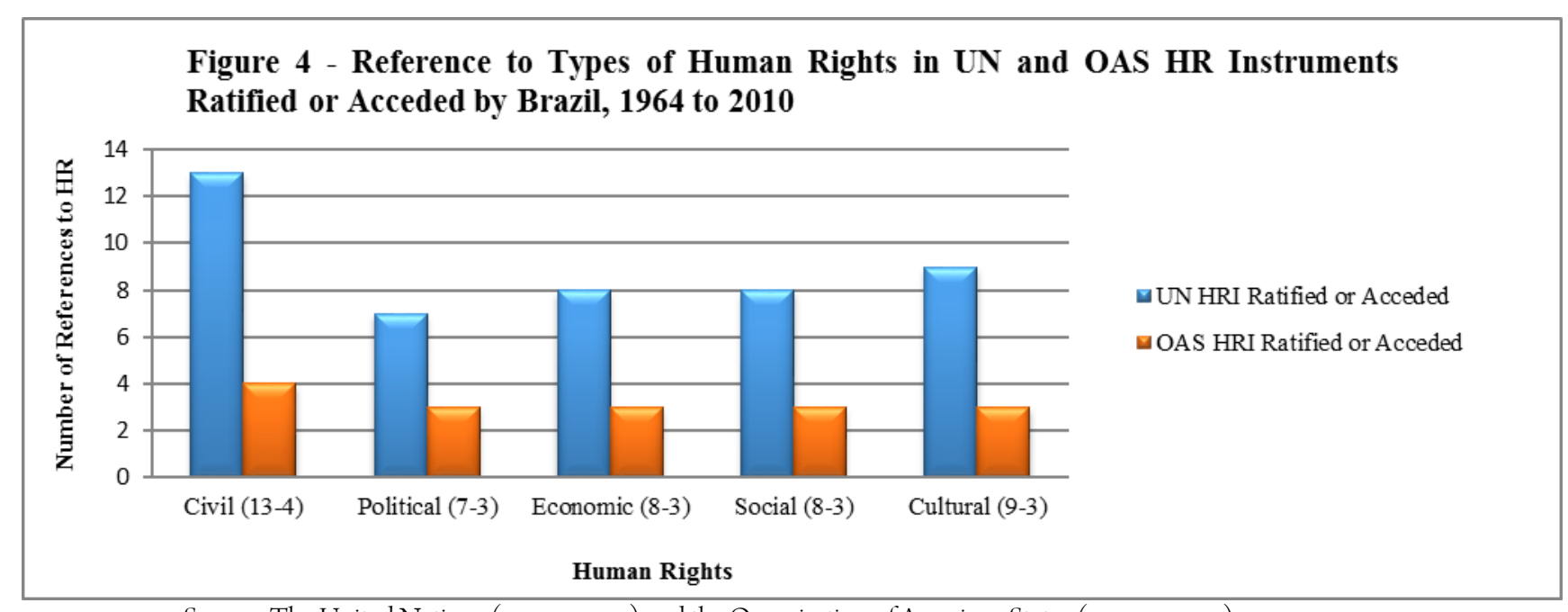

Source: The United Nations (www.un.org) and the Organisation of American States (www.oas.org)

Through the Brazilian transition to formal democracy there has been a progressive reception of human rights instruments by Brazil's legal system. The analysis of the types of rights referred to in the texts of each UN and OAS human rights instruments analysed here might help unveil some of the contradictions regarding the political, economic, cultural and social changes that influenced in the creation in 2004 of the PPDDH. As demonstrated by figure 4, for instance, concerning UN human rights instruments, despite the general subjects, it can be noted that the type of rights more referred to in the documents is civil rights. The next to come is the cultural rights, which is followed by both the social rights and cultural rights. The least referred to is the political rights. As for OAS human rights instruments, despite the general subjects, it can be observed that the type of rights more referred to in the documents is also civil rights, which is followed by the other equally-referred-to four types of rights (political, economic, social, and cultural ones). At first glance this might lead one to think that civil rights have been the main concern for Brazilian governments since 1964. However, it should be noted that an even more detailed analysis must be conducted in order for anyone to comprehend this particular set of circumstances better. In this sense, figure 5 describes the references to types of human rights (civil, political, economic, social and cultural) in UN and OAS ratified or acceded respectively, per Brazilian governments, from 1964 to 2010.

\footnotetext{
${ }^{82}$ Some instruments refer to more than one type of right simultaneously. So, each reference has been counted down to the analysis. vol.09, nº. 04, Rio de Janeiro, 2016.pp. 2263-2311 2290
} 


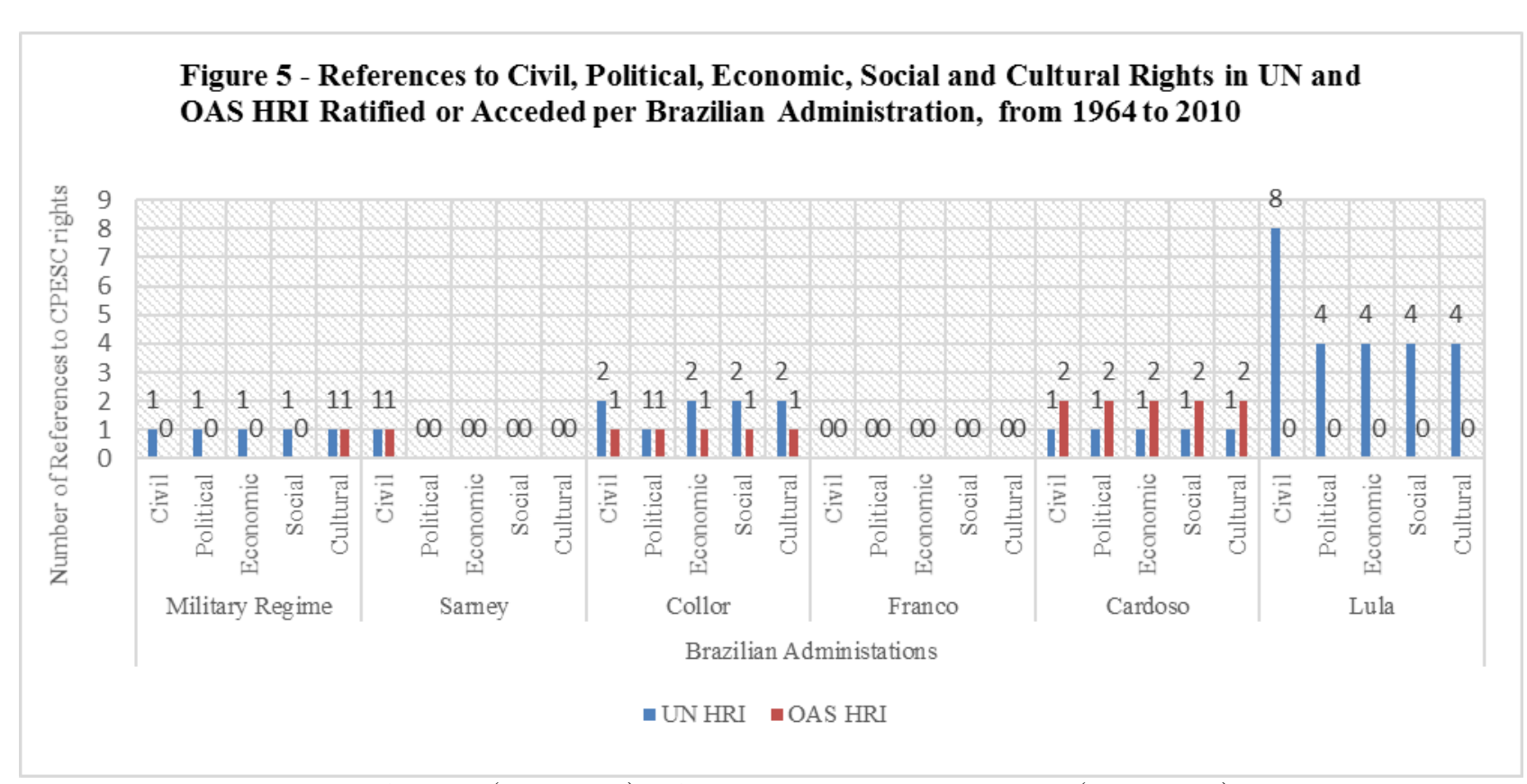

Source: The United Nations (www.un.org) and the Organisation of American States (www.oas.org)

Regarding UN human rights system, despite the general subjects, the two Lula Administrations ratified or acceded instruments whose type of rights more referred to in their texts is civil rights, which represents eight in total, and then political, economic, social and cultural rights, each of which with four references. The Collor Administration comes next with two references to civil, economic, social and cultural rights each, and one reference to political rights. Then comes the Military Administration and the two Cardoso Administrations with one reference to civil, political, economic, social and cultural rights each. Subsequently comes Sarney Administration with one reference to civil rights and no references to political, economic, social and cultural rights. Finally, there is the Franco Administration with no reference at all. As for OAS human rights system, also despite the general subjects, the two Cardoso Administrations ratified or acceded instruments whose type of rights more referred to in their texts are civil, political, economic, social and cultural rights, each of which with two references in total. The Collor Administration comes next with one reference to civil, economic, social and cultural rights each. Sarney Administration comes with one reference to civil rights and no reference to political, economic, social and cultural rights. The Military Regime appears with one reference to cultural rights and no reference to any other type of human rights. The remaining administrations (Franco and the two Lula ones) have no reference to any type of human rights at all.

It can be seen, therefore, that the analysis of the tables and figures indicate that through the authoritarianism the military regime ratified or acceded UN and OAS human rights instruments that refer to civil rights (1), political rights (1), economic rights (1), social rights (1), and cultural rights (2). Further, it also indicates that during the transition to democracy the Sarney Administration ratified or acceded UN and OAS human rights instruments that refer only to civil rights (2). Then, it indicates that in formal democracy the Collor 
Administration ratified or acceded UN and OAS human rights instruments that refer to civil rights (3), political rights (2), economic rights (3), social rights (3), and cultural rights (3); the Franco Administration ratified or acceded none; the two Cardoso Administrations ratified or acceded UN and OAS human rights instruments that refer to civil rights (3), political rights (3), economic rights (3), social rights (3), and cultural rights (3); and the two Lula Administration ratified UN and OAS human rights instruments that refer to civil rights (9), political rights (4), economic rights (5), social rights (4), and cultural rights (9). ${ }^{83}$ Hence, it can be observed that although the two Lula Administrations did not ratify any OAS human rights instruments, the UN instruments ratified during the Lula period make it the one with the highest numbers in all types of rights referred to by human rights instruments that have been identified in the analysis. ${ }^{84}$

Another important issue made evident by the tables and figures is that the Brazilian legal framework for the protection and promotion of human rights has been shaped in parallel with the strengthening of Brazilian democratic institutions. Thus, it is clear that democracy and human rights have really been walking side by side in Brazil's recent history. Further, this legal framework, developed within formal democracy, is complemented also by infra-constitutional legislation (federal laws and presidential decrees) that regulate specific themes such as women, gender, race, persons with disability, health, environment, and so forth. In general terms, it should be clear that although the Brazilian legal system has the 1988 Federal Constitution as one of its key elements, the utilization of complementary infra-constitutional legislation to regulate specific themes is also significant for the protection and fulfilment of fundamental rights in Brazil. ${ }^{85}$

Having conducted the taxonomy of the international and regional human rights instruments ratified or acceded by Brazil, the next section will apply the CDA approach in order to verify if Brazil's practices have followed its human rights rhetoric during authoritarianism, transition to democracy, and formal democracy phases in Brazil's recent history.

\section{Brazil's Practices and Human Rights Rhetoric: "Received Story versus Deeper Analysis"}

This section will apply the CDA approach in order to verify if some of Brazil's practices have followed its human rights rhetoric during authoritarianism, transition to democracy, and formal democracy phases in Brazil's recent history. By making connections among Brazilian Administrations (dimension 1), human rights policies or strategies (dimension 2), and human rights ratification or accession (dimension 3), the paper is now going to

\footnotetext{
${ }^{83}$ Ibid.

${ }^{84}$ This could be a good clue regarding the political change at the federal government level influencing the human rights policies.

${ }^{85}$ The Brazilian Legal System functions, at least formally, centred on the respect and protection of human dignity. This means that one will have his or her human dignity respected and protected by being able to fully enjoy their constitutional fundamental rights under the Brazilian jurisdiction. For an analysis of the human dignity in light of the 1988 Brazilian Constitution see Sarlet (2005 and 2004); Barcellos (2002); Barroso (2003).
} 
conduct a critical-contextual analysis with a tetrapartite approach and, therefore, it is going to analyse the phenomenon within the political, economic, cultural and social dimensions regarding the trades, causal chains, and ambiguities that are not only related to human rights issues during the Brazilian transition to democracy, but also able to unveil the reasons that led to the creation in 2004 of the PPDDH.

It should be noted that I have initially found myself facing two crucial questions regarding the conduction of the CDA approach towards the in-construction corpus, as follows: What is the best interpretation of the corpus? What line of action should be followed after the analysis of the corpus is initiated? Considering epistemological aspects that demand the pursuit of self-conscience and the appliance of reflexivity throughout the analysis; I have opted to conduct an interpretation of the corpus of analysis that could contribute better to the accomplishment of transformations in the Brazilian structures (dominant order). This means, therefore, that a critical approach towards the situation of violence against human rights defenders in Brazil has been taken in this paper. ${ }^{86}$ As mentioned earlier, the selection process for the construction of the corpus of analysis is an ongoing process. Therefore, it is important to consider that the human rights documents analysed in this paper represent a sample of an in-construction corpus of analysis. In this sense, the sample is composed by Brazil's Statements at the Opening of the $19^{\text {th }}, 32^{\text {nd }}, 34^{\text {th }}, 40^{\text {th }}, 45^{\text {th }}, 47^{t h}, 50^{\text {th }}, 54^{\text {th }}, 59^{\text {th }}, 60^{\text {th }}$, and $62^{\text {nd }}$ Sessions of the United Nations General Assembly and Presidential Inauguration Statements of 1964, 1985, 1990, 1992, 1995, 1999, 2003, and 2007. Their analysis follows below.

A military coup d'état introduced in March 1964 a dictatorial regime and constitutional guarantees in Brazil ceased. At the occasion of his inauguration ceremony, the military dictator Castelo Branco ${ }^{87}$ gave a speech in which no word referred to human rights at all. This silence (absence of discussion on human rights affairs) would be a constant pattern throughout the authoritarian regime (BONFIM, 2008). At the international level, however, although there was no human rights rhetoric by any account, the military regime's Minister of Foreign Affairs made a vague reference to the military government willing that the UN keep contributing to "the universal respect of fundamental rights of man" (CORREA, 1995, 187) in his statement at the Opening of the $19^{\text {th }}$ Session of the United Nations General Assembly. A similar reference would be found later on in the Minister of Foreign Affairs' argument regarding Brazil's apparent (or perhaps rhetorical) disposition to continue working to the strengthening of the United Nations contained in his statement at the Opening of the $34^{\text {th }}$ Session of the United Nations General Assembly. The use of the verb "to continue" indicates a contradiction, for it implies Brazil's military dictatorship had been working on the promotion and respect of human rights, whereas in reality it had violated human rights massively. The following passage sheds light to the mentioned contradiction:

\footnotetext{
${ }^{86}$ As it should be clear by now, I assume "[my] non-neutrality, [my] embarrassments and involvements, as well as limitations, accepting the full ethical responsibility for the presentation realized” in this paper. See Nogueira $(2001,37)$

${ }^{87} \mathrm{He}$ is the first one of a series of military dictators to be sworn in as "president" of Brazil. They would stay in power until 1985. vol.09, no. 04, Rio de Janeiro, 2016.pp. 2263-2311 
[...] Brazil will continue to work for the strengthening of the United Nations in the maintenance of international peace and security, cooperation for the development, and promotion of the respect for the rights of the human person and for fundamental liberties, without distinction of race, sex, language or religion. (CORREA, 1995, 354)

An ambiguity refers to the fact that the pressures made by the Carter Administration (USA) forced the military regime to reserve significant space for human rights in the Minister of Foreign Affairs' statement at the Opening of the $32^{\text {nd }}$ Session of the United Nations General Assembly. Nevertheless, although there is explicit reference to human rights in the statement, the approach is a negative one. In fact, it is clear the efforts to avoid an open discussion on human rights violations in Brazil. Thus, it is possible to infer that, on the one hand, there is a "negation" or "denial" (via silence or omission) of the existence of human rights issues in Brazil; on the other hand, that the "negation" or "denial" (again, via silence or omission) could be an indicative of the existence of human rights violations in the country. Further, the statement does not use the term "human rights" solely. Instead, it uses the terms "rights of men" and "human rights" alternatively. To negate or deny the discussion of human rights as an issue in Brazil, the statement uses two arguments: (1) the nuclear weapons race and existing inequalities in the world prevent the full realization of human rights globally; and (2) the exclusive competence of States to deal with human rights problems in their domestic jurisdiction (CORREA, 1995, 187). The following passages are representative of the efforts to avoid an open discussion on the existence of human rights violations in Brazil:

The UN Charter puts the theme of the Rights of Men precisely in the field of international cooperation and, in this sphere, makes of their promotion one of the important tasks of the UN. [...] (CORREA, 1995, 338)

$[\ldots]$ Brazil has just joined the works of the Commission of the Rights of Men, which will allow it to contribute in a more effective way, within the international normative, to the promotion of those rights. The mechanisms and procedures already at the disposal of the UN for the consideration of the problematic of human rights seem to be ample and sufficient for the task to proceed in a pace that the complexity of the matter demands and guarded against temporary factors and circumstances. (CORREA, 1995, 339)

In general terms, even though two UN human rights instruments (CERD and CEDAW) were ratified during the authoritarianism phase, there is no apparent connection among the military dictatorship, human rights ratification or accession, and human rights policies or strategies, particularly due to the fact it was an authoritarian regime and neither a human rights rhetoric no a governmental culture of human rights existed.

About twenty years later, in April 1985, the transitional phase started. At the occasion of the first cabinet meeting of the New Republic, the Vice-President-elect José Sarney delivered a statement written by the Presidentelect Tancredo Neves ${ }^{88}$ in which no word refers to human rights at all. Later on, in July 1985, the President José Sarney delivered what he considers to be his presidential inauguration statement in a TV and radio national

\footnotetext{
${ }^{88}$ There are two statements that could be interpreted as the Presidential Inauguration Statement for the transitional government. The first one was written by the President-elect Tancredo Neves and delivered by the Vice-President-elect José Sarney due to the fact the former had gotten suspiciously sick and was hospitalized. He came to die later on in very suspicious circumstances. The second was written and delivered by the then already sworn in President José Sarney in a TV and radio national broadcast. Although he delivered both, "the speech José Sarney considers as being his inauguration statement" is the second one. In Bonfim vol.09, nº. 04, Rio de Janeiro, 2016. pp. 2263-2311 2294
} 
broadcast. Again, no word refers to human rights. At the international level, however, as an innovation of the Sarney Administration, the human rights rhetoric is definitively present in President Sarney's statement at the Opening of the $40^{\text {th }}$ Session of the United Nations General Assembly. The following passages are noteworthy:

Human rights acquire a fundamental dimension, strictly linked to the very practice of coexistence and pluralism. (CORREA, 1995, 441)

The Universal Declaration of Human Rights is, without doubt, the most important document firmed by men in contemporaneous History. And it was born in the United Nations. [... ] With pride and confidence, I bring to this General Assembly the decision to adhere to the International Covenants on Civil and Political Rights, to the Convention against Torture and Other Cruel, Inhuman or Degrading Treatment or Punishment, and to the International Covenant on Economic, Social and Cultural Rights. With these decisions, the Brazilian people takes a step towards the democratic affirmation of its State and reiterates, before itself and the whole international community, the solemn fulfilment of the UN Charter principles and with the promotion of the human dignity. (CORREA, 1995, 442)

There seems to be a contradiction between Brazil's practice and human rights rhetoric regarding the latter passage, for the ICAT would be ratified only in 1989 (by the Sarney Administration, but four years later) and the ICCPR and ICESCR acceded only in 1992 (by the Collor Administration). In any case, it is accurate to say that this statement marks a change in the Brazilian Foreign Policy which was conducted during the authoritarian period. In general terms, it is important to consider that as the two human rights instruments (UN's ICAT and OAS's ICPPT) that were ratified during the transition to democracy phase emphasize civil rights, and that the Sarney Administration took at least one concrete action in creating the National Council for the Defence of Women Rights, ${ }^{89}$ there seems to be a connection among the Sarney Administration, human rights ratification or accession, and a human rights strategy (directed to the defence of women rights). However, although human rights rhetoric is initiated in the transitional phase, no governmental culture of human rights existed yet (see Table 1).

Twenty-five years after the military coup d'état, which had introduced a dictatorial regime, Brazil was finally concluding its transition to formal democracy with the direct election of Fernando Collor de Mello as President of Brazil. At the occasion of his inauguration ceremony in 1990, he gave a speech in which there is a clear mention to human rights and its strong connections to democracy. It is perhaps attesting that human rights had already been assimilated at the federal level of government. The following passages are noteworthy:

Brazil, one of the biggest democracies in the world, cannot but figure ahead of this universal movement of liberation of mankind and of the generalization of the priceless practice of selfgovernment, of the rule of law, and of the strict observance of human rights. (BONFIM, 2008, 344)

The Cold War is definitively buried. Alliances are being rethought. Alignments are being

(2008, 317). The analysis being conducted in this paper considers both of them.

${ }^{89}$ It was created in August 1985 and conducted campaigns to support the participation of women in the National Constitutional Assembly process as much as the so-called "Lobby do Baton" (the Lipstick Lobby). It had the majority of its demands included in the text of the new Constitution of 1988. Secretaria de Políticas para as Mulheres <http://www.sepm.gov.br/conselho/historico/historico> accessed 20 October 2016. 
cancelled. Meanwhile, new areas are preparing to adopt the laws of market economy, with democracy, respect for human rights and culture of liberty, which are today universal tendencies. (BONFIM, 2008, 350)

I will insist on the idea that permanent peace could not be constructed based on anything but on solid rules of good relations, such as the respect of sovereignty, the non-intervention, the self-determination, the peaceful resolution of conflicts, the respect to treaties, the integral respect of human rights. (BONFIM, 2008, 351)

With about twenty paragraphs directed to foreign policy, President Collor's presidential inauguration statement makes clear Brazil's aspirations to become a bigger player in world politics, as demonstrated by another passage:

One of the emphases of modern Brazil must be its active participation in the grand international decisions. Not for the pursuit of hegemony or will of power, which the Brazilian tradition rejects. But because, today, interdependency requires that each governmental act be a permanent combination of internal and external variables. For a country of our dimensions, with our determination to development, there is no better option than to take active part in international decisions. (BONFIM, 2008, 351)

This is in consonance with President Collor's statement at the Opening of the $45^{\text {h }}$ Session of the United

Nations General Assembly, which shows clear human rights rhetoric as demonstrated by the following passages:

I could not, Mister President, refrain from mentioning the importance that has received in our common agenda the human rights thematic. With the spread of the democratic ideals, it will be even more incisive and amplified the international treatment of this question. (CORREA, 1995, 518)

[... The violations of human rights must be denounced and combated with equal rigor, wherever they occur. In this camp, one of my fundamental preoccupations is with the preservation of the life and traditions of indigenous communities in Brazil. (CORREA, 1995, 518)

$[\ldots]$ the international community has an important role to play in order to create the world conditions for the guarantee of respect to human rights in its more ample conception. (CORREA, 1995, 518)

[... Human rights must be increasingly extended as a whole, without artificial or particular distinctions among its ramifications. (CORREA, 1995, 519)

In general terms, as the four human rights instruments (UN's CRC, ICCPR, and ICESCR; and OAS's ACHR) that were acceded during the Collor Administration emphasize civil, economic, social and cultural rights, followed by political rights, and that that administration took concrete actions to ensure the investigation of human rights violations cases denounced by national and particularly transnational NGOs, it is clear the connection among the Collor Administration, human rights ratification or accession, and a human rights strategy. In fact, it should be noted that Brazil's practices and human rights rhetoric combine at some instances during this period, particularly due to fact the governmental culture of human rights was being germinated at the federal level.

At the occasion of his presidential inauguration in 1992, President Franco gave a speech in which no word refers to human rights. Nonetheless, at the international level his Minister of Foreign Affair's statement at the Opening of the 4th Session of the United Nations General Assembly was unprecedentedly generous regarding the space reserved for human rights. It was the first statement to reserve eleven paragraphs on human rights rhetoric. In fact, perhaps it is plausible to infer that from this statement on the human rights rhetoric started being vol.09, nº. 04, Rio de Janeiro, 2016.pp. 2263-2311 
taken seriously by Brazil. In this regard, the question which arises is: If this is the case, why is it so? Without getting into its core, the issue seems to unveil that a strategy for Brazil's foreign policy had already been conceived and would have human rights rhetoric as one of its central elements. The following passages are noteworthy:

In the human rights field, it has fortunately been developed a new perception regarding the special necessity to protect the most vulnerable groups in each country. [...] (CORREA, $1995,547)$

$[\ldots]$ we must concern with shortening to the maximum extent the distance that separates the realizable from the desirable. The respect of human rights must be universal, as universal is the Declaration of 1948, and universal are the dispositive norms of treaties and conventions that codify the matter. In short words, human rights must not be violated under any excuse. [... The Brazilian Government makes all possible efforts for the defence and protection of human rights. We keep an open dialogue with international governmental and non-governmental organizations, and we adhered to the main conventional instruments that regulate the matter. $[\ldots]$ The respect of human rights and the equality of all before law are absolute values. [... ] (CORREA, 1995, 548)

By and large, as President Franco neither ratified nor acceded any UN or OAS human rights instruments, there is no apparent connection among his administration, human rights ratification or accession, and human rights policies or strategies. Nevertheless, given the initiatives taken by his government (see Section 2 above) towards human rights issues domestically, it is possible to say that both human rights rhetoric and a germinating governmental culture of human rights existed.

With the support of his predecessor's and having benefited from the stabilization of the economy, which is said to derive from his work as President Franco's Minister of Treasure, President Cardoso in 1995 delivered a presidential inauguration statement in which human rights is referred to just once and as part of the broader topic "human rights and democracy". In fact, although there are direct references to gender, ethnicity and race questions, it is more accurate to interpret the reference to human rights as part of a point in his statement that makes clear Brazil's aspirations to play a more significant role in global politics and economy, as follows:

It is time to debate clearly what must be Brazil's profile, as a sovereign Nation, in this changing world, involving in the debate the Chancellery, the Congress, the university, the unions, the companies, the non-governmental organizations. We will retire the old ideological dilemmas and the old ways of confrontation, and face the themes that move the cooperation and the conflict among countries nowadays: human rights and democracy; environment and sustainable development; the amplified tasks of multilateralism and the challenges of regionalization; the empowerment of the international trade and the overcoming of the ways of protectionism and unilateralism. $[\ldots]$ We will valorise to the maximum the universal condition of our presence, as much political as economic. (BONFIM, 2008, 378-379)

At the international level, however, President Cardoso's Minister of Foreign Affairs' statement at the Opening of the $50^{\text {th }}$ Session of the United Nations General Assembly contains clear human rights rhetoric. In fact, keen on demonstrating a "new image of renovation and stability" (CORREA, 1995, 582) to the world, the first UN statement of the Cardoso Administration makes clear that the government is working in partnership with civil society on dealing with human rights issues, which is also argued in his presidential inauguration statement. The 
following passages are noteworthy:

I am proud in occupying this floor as the representative of a country which has amplified its commitments with democracy and human rights $[\ldots]$ While determining the application of the existing mechanisms, President Fernando Henrique Cardoso proposes legislation that will secure the full observance of human rights. As much in the internal sphere as in the external one, the Brazilian policies on human rights are based on transparency and cooperation with civil society. Together with the decisive Governmental action to tackle the social problems of the country, the measures designed to the promotion and protection of human rights will contribute significantly to reverse the unjust scenario of income distribution that unfortunately still predominates in Brazil. (CORREA, 1995, 586)

After being re-elected, at the occasion of his second term inauguration ceremony in 1999, President

Cardoso delivered a speech in which there is no direct reference to human rights. Violence, the rights of children, women, afro-Brazilians ${ }^{90}$, and indigenous peoples, and the strengthening of Brazil's Human Rights Secretariat are themes approached directly, as demonstrated by the following passage:

There is no democracy where subsist violence. Where the basic rights of children and women, of blacks and indigenous are still disrespected. We advanced in this area. But we need to do more. The challenge is in transforming the values and norms into quotidian practices. The Human Rights Secretariat was strengthened institutionally to accomplish its mission. Society will be invited to participate more directly in the execution and control of policies. (CORREA, 1995, 596)

Instead of human rights rhetoric, the main point in his discourse is the legitimization of a neoliberal agenda and the transformation of Brazil into a (neoliberal) reduced state (the minimum state). At the international level, the President Cardoso's Minister of Foreign Affairs' statement at the Opening of the $54^{\text {th }}$ Session of the United Nations General Assembly does not contain a direct reference to human rights and its respective connection to the Brazilian governmental action. Instead, it seems to comply with the government call for democracy and neo-liberalism. The reference to human rights is related (and limited) to a point on the redemocratization of Latin American countries. The following passage is noteworthy:

In the decade that is about to end, the Latin America, long seen as a land of underdevelopment and dictatorships, was able to construct a new international image, beginning from the transformation of its reality. The re-democratization of our countries was a decisive factor for this happening, as were the important advancements that we realized in the field of fights for the respect of human rights, despite there is still much to be done. (CORREA, 1995, 655)

In general terms, as the four human rights instruments (UN’s CEDAW-OPT; and OAS’s ICPPEVAW, AP-ACHR-ESCR, and OP-ACHR-ADP) that were ratified or acceded during the two Cardoso Administrations emphasize civil, political, economic, social and cultural rights, and that concrete actions (see Section 2 above) were taken towards facing human rights issues and dialoguing with national and transnational NGOs, it is clear the connection among the two Cardoso Administrations, human rights ratification or accession, and human rights policies or strategies. It is fair to argue that Brazil's practices and human rights rhetoric combined here much more often than otherwise, especially due to fact the governmental culture of human rights is significantly developed at 
the federal level during this period.

At the occasion of his inauguration ceremony in 2003, President Lula made a statement in which human rights are referred to just once and as part of an argument towards the strengthening of the United Nations. Here is the passage:

We will support the efforts to make the UN and its agencies agile and efficient instruments in the promotion of social and economic development, in the combat against violence, inequalities and all forms of discrimination, in the defence of human rights, and in the preservation of environment. (BONFIM, 2008, 414-415)

In this aspect, although there is no human rights rhetoric per se, it is clear the President Lula's intentions to make governmental efforts towards placing Brazil in a more significant economic and political global position. This could be a clue regarding his decision to later on create by a presidential decree the National Policy for the Protection of Human Rights Defenders, to which the PPDDH is part. The following passage is noteworthy:

Brazil can give a lot to itself and to the world. Because of this we must demand a lot from ourselves. We must demand even more than we thought, because we have not expressed ourselves entirely in our History, because we have not yet accomplished the great planetary mission that awaits us. (BONFIM, 2008, 415)

The same logics persists at the international level, for President Lula's statement at the Opening of the $58^{\text {th }}$ Session of the United Nations General Assembly does not contain human rights rhetoric per se, despite the strong point that he makes on the war against hunger and misery. The indirect reference to human rights is linked to the argument regarding the political strengthening of the UN General Assembly. The following passages are noteworthy:

The General Assembly, in its turn, needs to be politically strengthened in order to, without dissipating efforts, dedicate itself to the priority themes. The General Assembly has played a relevant role by convoking the great Conferences and other meetings on human rights, environment, population, women rights, racial discrimination, AIDS and social development. (CORREA, 1995, 705)

$[\ldots]$ We need to engage ourselves with the war in which we all will come out as victors: the war against hunger and misery. To eradicate hunger is a moral and political imperative. And all of us know that it is accomplishable. If there were - de facto - political will to do so. (CORREA, 1995, 707)

Directly related to Brazil's aspiration to become a bigger player in world politics is the following passage:

Beyond strengthening the relations already very much relevant with our traditional partners in North America and Europe, we seek to amplify and diversify our international presence. (CORREA, 1995, 706)

An ambiguity can be identified in the President Lula's Minister of Foreign Affairs' statement at the Opening of the $60^{\text {th }}$ Session of the United Nations General Assembly, which put strong emphasis on human rights with the use of four paragraphs in total. See the next passages:

${ }^{90}$ Note that the original uses the term "blacks" instead of "afro-Brazilians". 
The UN human rights structures and mechanisms must be backed-up and improved. We support the creation of a Human Rights Council that would base itself on the principles of universality, dialogue, and non-selectivity. The elaboration of a global report on human rights, under the responsibility of the High Commissioner for Human Rights, which covers all countries and situations, will contribute to the increase of credibility of the UN human rights protection system. [...] The General-Secretary urged us to work in a more coordinated way in direction to the protection of victims of grave and systemic human rights violations. [...] (CORREA, 1995, 752)

[...] We will keep giving support to a bigger international cooperation to the combat of terrorism and to the elimination of its profound causes. These efforts must respect international law and human rights. [... (CORREA, 1995, 754)

It should be noted that this is the year in which the Lula Administration faced a serious crisis regarding the scandals of corruption involving members of the government. The "Mensalão crisis" almost led to the impeachment of President Lula. ${ }^{91}$ Yet, there is no mention at all to this internal political crisis in the statement concerning the Brazilian foreign policy. The ambiguity rests, thus, on the fact that no word refers to the scandals of corruption in the federal government that were occurring domestically. The absence of domestic human rights rhetoric, despite the governmental culture of human rights was consolidated during the period, in contrast with a strong emphasis on human rights at the UN, might indicate a deliberate attempt to prevent the corruption topic from damaging Brazil's (and for that matter President Lula's) image both internally and abroad.

In spite of the scandals of corruption, after being re-elected, at the occasion of his second term inauguration ceremony in 2007, President Lula delivered a speech ${ }^{92}$ in which no word refers to human rights at all. The same silence occurred at the international level, for there is no human rights rhetoric in President Lula's statement at the Opening of the $62^{\text {nd }}$ Session of the United Nations General Assembly, despite the strong point that he makes on the fight against hunger and poverty. Another ambiguity perceived here refers to the silence (absence of human rights rhetoric) contrasted to some efforts made internally concerning human rights issues as, for instance, the approval of the Brazilian Policy for the Protection of Human Rights Defenders via the Presidential Decree 6.044/2007, which was signed by President Lula. In general terms, as the eight UN human rights instruments (CRC-OPT-AC, CRC-OPT-SC, ICAT-OPT, CRPD, CRPD-OPT, CCPR-OPT, CCPR-OPT1, CCPR-OPT2, and CPED) that were ratified or acceded during the two Lula Administrations emphasize civil and cultural rights, followed by economic rights and then by political and social rights, and that significant actions (see Section 2 above) were taken concerning human rights issues, it is clear the connection among the two Lula Administrations, human rights ratification or accession, and human rights policies, programmes and strategies. Here as well, Brazil's practices and human rights rhetoric are combined more often than not, especially due to fact the governmental culture of human rights is consolidated at the federal level during this period.

\footnotetext{
${ }^{91}$ The "Mensalão crises" led to criminal lawsuits. Eventually, Ministers members of President Lula's cabinet were prosecuted, convicted and arrested.

92 BBC Brasil <http://www.bbc.co.uk/portuguese/reporterbbc/story/2007/01/printable/070101_luladiscurso2_ac.shtml> accessed 20 October 2016.
} 
Another contradiction refers to the fact President Lula reached power with unprecedented potential to implement real structural changes in the country (PAULA, 2011). And he was aware of the historical momentum, as shown in his first presidential inauguration statement in 2003, as follows:

We are in a particularly opportune moment to do this. A moment in which the President of Brazil has, on his side, the national will. The business class, the political parties, the Army and the workers are united. The men, women, the elderly, the youngest, are united in the same goal to contribute for Brazil to fulfil its historical destine of prosperity and justice. (BONFIM, 2008, 410)

According to Flynn (2005), the reason for the first Lula Administration's lack of concrete actions towards structural changes rests on (1) the existence of external economic pressure; (2) the bureaucratization of the Workers' Party; (3) the existence of a 'new class' (OLIVEIRA, 2003); and (4) 'nepetism'93. Nevertheless, it is still necessary to ask: Why then were some efforts on human rights internal and foreign policies made and some results achieved? Some emphasis should be put here on the fact that the paralysis of the first Lula Administration concerning changing the material basis of Brazilian society does not mean any advancement could not be accomplished at all. In fact, poverty reduction programmes are good examples of advancements in social policies under the first Lula Administration, particularly the Fome Zero and Bolsa Família programmes (HALL, 2006; FENWICK, 2009). Another significant example is the PPDDH's creation in 2004. ${ }^{94}$ However, the fact that the first Lula Administration focused on programmes more than structural reforms as well as "Lula's subsequent pleas for patience reflected growing awareness of how hard it might be to change Brazil [ ... ]" (FLYNN, 2005, 1229).

While Cardoso's was a government of reforms, Lula's has been a government of programmes, a qualitative difference. The reform path pursued by the Cardoso government required entering into lengthy negotiations and achieving high-threshold votes in Congress in order to implement unpopular policies, such as privatizing state firms, breaking up monopolies, and amending labour laws. The Lula government's social policy accomplishments are programmes controlled by the executive, which do not require legislative wrangling to be enacted. Targeted social policies, moreover, produce more immediate electoral returns than the structural reforms of the Cardoso years, and their very nature - being so concrete, visible, and immediately beneficial - invites far wider credit claiming by politicians. Lula has proven most adept in this regard. By sharing the day-to-day operation of Bolsa Familia with Brazil's 5,500 municipal mayors, the president has allowed local elites to reap some of the benefits of this hugely popular programme. (HUNTER AND POWER, 2007, 17-18)

Thus, it is evident that the scandals of corruption are an indicative of the necessity and even urgency concerning the construction of a new cultural politics in Brazil (DAGNINO, 1998). Further, they make clear that

\footnotetext{
${ }^{93}$ The expression refers to "pork-barrel" practices by the Workers' Party once having reached power. See Flynn (2005); Avritzer (2006); Amaral (2010).

${ }^{94}$ Despite the fact President Lula signed Presidential Decree 6.044/2007 only in 2007. This decree approved the National Policy for the Protection of Human Rights Defenders. Much later on, President Rousseff via the Presidential Decree 8.724, of 27 April 2016, would institute the PPDDH. For more details see Terto Neto (2016 b).
} 
democratization and human rights must continue walking together towards addressing social authoritarianism and thus accomplishing social justice in the country. In fact, the Brazilian transition from authoritarianism to formal democracy reinserted Brazil into the logic of promoting, protecting and respecting human rights (PIOVESAN, 2008) and, as described earlier, the strengthening of its democratic institutions has occurred in parallel with the institutionalization of regional and international norms and the development and consolidation of a governmental culture of human rights in the country. Within this context, despite the controversies and given all the advancements otherwise, the fact is that human rights violations are still a routine in the lives of millions of Brazilians. About twenty-eight years have passed since the promulgation of the 1988 Brazilian Constitution, so has there been enough time for the constitutional ideals to modify structurally the persistent occurrence of human rights violations in Brazil? Why does the contradiction "constitutional formalism versus material exercise of fundamental rights" persist? Although the 1988 Brazilian Constitution represented a new phase in the history of Brazilian Law, one should not forget that law per se is never enough to realize structural changes in any society. Advancements beyond constitutional and infra-constitutional formalism are necessary for the material enjoyment of fundamental rights by everyone under the Brazilian jurisdiction. It seems, therefore, that human rights discourse and practices must combine and manifest into political action to bring about effective social change in Brazil. The dilemma refers, therefore, to the fact structural obstacles to citizenship must be tackled in order for the achievement of full citizenship to be achievable (PINHEIRO, 1998; PICQ 2004). In this regard, formal democracy and law per se have not been enough to bring about human rights change in the country, for a revolutionary project of society with a new cultural politics must be established if the historical structures are ever to be radically changed. It is necessary to consider, therefore, that through all aforementioned phases in recent Brazilian history the roles played by human rights defenders have been significant by any means. In fact, through this process in which Brazil has been transforming itself - from an authoritarian military dictatorship into a formal democratic regime ruled by law - social struggles for democracy and human rights have not occurred without reaction from conservative and powerful forces, which have controlled the economic and political mechanisms (OLIVEIRA, 1999). Rather, the elite's reactions to those social struggles have been not only strong, but also very damaging for popular and social movements. Threats and the criminalization and killing of well-known human rights defenders who organize and carry out fights for rights have not only unveiled the contradictions between subjects (agents) from dominant and dominated sectors, and their structures, in the pursuit of economic, political and symbolic powers toward the establishment of hegemony, ${ }^{95}$ but also, become routine in Brazil.

\footnotetext{
${ }^{95} \mathrm{Ibid}(\mathrm{n} 67)$
} 


\section{CAUSAL CHAINS THAT EXPLAIN THE PPDDH'S ESTABLISHMENT}

At this stage it should be possible to argue for the existence of a set of causal chains that might help us understand the establishment of the PPDDH. The political causal chain refers to the re-democratization of the country, that is, its shift from authoritarianism to formal democracy that has made possible an increase in the reception of international and regional human rights instruments as well as the surge and development of a governmental culture of human rights. Thus, it is accepted that some progress has been achieved regarding human rights affairs in Brazil. The economic causal chain refers to the stabilization and growth of the Brazilian economy, that is, its shift from external debt and inflation (during authoritarianism and transition to democracy phases) to lending money to the IMF and becoming the one of the biggest economies in the world (during the formal democracy phase, until 2010). The social causal chain refers to the idea of civil society and civility, that is, the shift in the way people are relating to each other and, for that matter, the shift in the way people perceive the state (from an oppressive entity during the authoritarianism phase to an entity that can be demanded to protect rights and provide services and assistance during the formal democracy phase. The cultural causal chain refers to the construction of a new cultural politics, that is, the consolidation of Brazilian democratic institutions and the protection, promotion and respect of human rights leading to a society in which the enjoyment of rights would be possible for all indiscriminately. In this regard, it can be seen that the human rights activism has shift from struggles for democracy (during the authoritarian phase) to struggles for improving the quality of Brazil's current formal democracy. ${ }^{96}$ As for the particular characteristics of this social process, it could be inferred that the establishment of the PPDDH occurred within a context in which Brazil was, on the one hand, facing scandals of corruption internally, all of which linked to its pre-existing structures that have historically thwarted human rights and prevented the Brazilian institutions to become fully democratic; and, on the other hand, increasing its political leadership and economic power abroad, both related to its aspirations to become a bigger player in world politics (TERTO NETO, 2016 a). Meanwhile, despite some tiny perceptual reduction in the levels of violence, poverty, exclusion, etc., state and non-state violence against human rights defenders was still very high (TERTO NETO, 2016 a). This is an ambiguity evidenced by the killings, threats, criminalization and stigmatization of human rights defenders that occurred (and are still occurring) in Brazil.

\footnotetext{
${ }^{96}$ These causal chains are indeed interdependent and interconnected. Thus, the analysis has been conducted considering all of them.
} vol.09, nº. 04, Rio de Janeiro, 2016.pp. 2263-2311 


\section{CONCLUSION}

The CDA approach has been undertaken in order to critically analyse parts of Brazil's official statements throughout the re-democratization of the country. This has made possible the reconstruction of some parts of Brazil's human rights discourse, both domestically and abroad. Nonetheless, there is still uncertainty. Thus, another question that arises is: What are the main contradictions between Brazil's practices and human rights rhetoric? In light of the political, economic, social and cultural changes that have occurred throughout the Brazilian transition to formal democracy I can argue that the main contradictions are:

1. The ratification or accession of international and/or regional human rights instruments does not necessarily lead to a governmental action towards the protection of the particular type of human rights regulated by the ratified or acceded treaty.

2. The absence of ratification or accession of international and/or regional human rights instruments does not necessarily impede governmental action towards human rights issues domestically.

3. An institutionalized governmental culture of human rights does not always translate into concrete governmental action towards structural changes that would address social authoritarianism and make social justice more likely to be accomplished than otherwise.

4. Human rights rhetoric can be (and very often is) (mis)used by governments to divert national and international attention from internal political crisis and maintain the current dominant order.

5. There is a gap between the formal constitutional guarantees and the "law enforcement" by the Brazilian State regarding the promotion, protection, and respect of human rights. Thus, advancements beyond constitutional and infra-constitutional formalism are necessary for the material enjoyment of fundamental rights by everyone under the Brazilian jurisdiction.

As a result, it can be argued that Brazilian State's practices have not always followed its human rights rhetoric, as already shown by the aforementioned causal chains, contradictions, and ambiguities. Furthermore, there is also uncertainty in regard to the Brazilian State's obligation as to the protection of human rights defenders. Consequently, a still unanswered question is: Are the Brazilian State's practices really following its rhetoric towards the protection of human rights defenders in the country? The Brazilian State's practices seem to be following its human rights rhetoric when it comes to the protection of human rights defenders in the country. In fact, irrespective of problems in terms of its scale and functioning, the establishment of the PPDDH has been a positive experience towards facing state and non-state violence against human rights defenders in Brazil. ${ }^{97}$ This due to the

\footnotetext{
${ }^{97}$ President Rousseff s impeachment impacted on Federal Government's human rights policies, especially since the Human Rights Secretariat lost its status of ministry and was reallocated into the new Ministry of Justice and Citizenship. However, although the PPDDH's activities were very limited throughout the "parliamentarian coup", the Temer Government has nevertheless preserved the programme. For details on the PPDDH's functioning and the perceptions of its own stakeholders (protected human rights vol.09, nº. 04, Rio de Janeiro, 2016. pp. 2263-2311 2304
} 
fact the PPDDH has been able to protect those human rights defenders who have somehow been included in it as well as strength their human rights fights (militancy). ${ }^{98}$ First, it has kept human rights defenders alive by providing them with protection, which also involves physical protection via 24-hours police surveillance. Second, it has provided medical, psychological, and financial assistance to them. In any case, by and large, this means that Brazil has reacted to the Brazilian civil society organization's demands as well as international pressures from human rights NGOs and UN and OAS mechanisms and started addressing the issue violence against human rights defenders domestically (TERTO NETO, 2016 a). Although much needs to be done, it can be argued nonetheless that at least when it comes to this specific issue - state and non-state violence against human rights defenders Brazil's practices seem to be in alignment with its human rights rhetoric.

\section{FAZENDO A RETÓRICA DE DIREITOS HUMANOS VALER: ESTÃO AS PRÁTICAS DO ESTADO BRASILEIRO REALMENTE SEGUINDO SUA RETÓRICA PARA A PROTEÇÃO DE DEFENSORES(AS) DOS DIREITOS HUMANOS NO PAÍS?}

\section{Resumo}

Este artigo considera a interação do direito internacional, da política e da legislação nacional na política de direitos humanos no Brasil por meio de governos democráticos brasileiros pós-1985, com referência ao surgimento de uma cultura governamental de direitos humanos, bem como da institucionalização de 1964 a 2010 dos direitos humanos internacionais no ordenamento jurídico do país. Com base na Análise Crítica do Discurso (ACD), ele compara, por um lado, os instrumentos internacionais de direitos humanos ratificados pelo Brasil e, por outro lado, as amostras significativas de documentos de direitos humanos relacionados com a transição brasileira para a democracia. Ao revelar influências das mudanças políticas, econômicas, sociais e culturais (evolução) para a criação do Programa Brasileiro para a Proteção de Defensores(as) dos Direitos Humanos (PPDDH), ele finalmente se envolve com as questões de saber se as práticas do Estado brasileiro seguem a sua retórica dos direitos direitos, bem como se as práticas do Estado brasileiro estão realmente seguindo sua retórica de direitos humanos para a proteção de defensores(as) dos direitos humanos no país.

Palavras-chave: Política dos Direitos Humanos; Direitos Humanos Internacionais; Programa Brasileiro para a Proteção de Defensores (as) dos Direitos Humanos; Análise Crítica do Discurso (ACD).

\section{REFERENCES}

ALVAREZ, Sonia E., DAGNINO, Evelina and ESCOBAR, Arturo (eds.), Culture of Politics, Politics of Culture: Re-visioning Latin American Social Movements (Westview Press, 1998).

defenders, civil society actors and state agents) see Terto Neto (2016 a).

${ }^{98} \mathrm{Ibid}$. 
ALVES, Jose Augusto Lindgren, Os Direitos Humanos como Tema Global (Perspectiva, 2011).

AMARAL, Oswaldo, 'Adaptação e Resistencia: o PT no Governo Lula entre 2003 e 2008', [2010] Revista Brasileira de Ciência Politica 4, pp. 105-134.

AMORIM, Celso, 'Brazilian Foreign Policy under President Lula (2003-2010): an Overview', [2010] Revista Brasileira de Politica Internacional 53, pp. 214-240.

ARENDT, Hannah, The Origins of Totalitarianism (Harcourt Brace \& Company, 1976).

ARNS, Paulo Evaristo, Brasil: Nunca Mais (Vozes, 2003).

AVRITZER, Leonardo, 'La crise du Parti des travailleurs: de la démocratie participative au désenchantement politique', Mouvements, $2006 / 5$ no $47-48$, p. $25-35$. DOI : $10.3917 /$ mouv.047.0025, available at http://www.cairn.info/revue-mouvements-2006-5-page-25.htm.

BARCEllos, Ana Paula de, A Eficácia Jurídica dos Princípios Constitucionais: o Principio da Dignidade da Pessoa Humana (Renovar, 2002).

BARROSO, Luís Roberto, O Direito Constitucional e a Efetividade de suas Normas: Limites e Possibilidades da Constituição Brasileira (Renovar, 2003).

BITTAR, Eduardo C. B. and ALMEIDA, Guilherme Assis de (eds), Mini Código de Direitos Humanos (Secretaria Especial de Direitos Humanos, 2010).

Bonfim, João Bosco Bezerra, Palavra de Presidente: Os discursos presidenciais de posse, de Deodoro a Lula (LGE Editora, 2008).

BUENO, Eduardo, Brasil: Uma História - Cinco Séculos de Um País em Construção (Leya, 2010).

BOURDIEU, Pierre, O Poder Simbólico (Rio de Janeiro: Bertrand Brasil 1998).

A Miséria do Mundo (Petropolis: Vozes 1997).

Razões Praticas sobre a Teoria da Ação (Campinas: Papirus 1996).

BRYSK, Alison. 'From Above and Below: Social Movements, the International System, and Human Rights in Argentina', [1993] Comparative Political Studies 26 (3): 259-285.

BUZAN, Barry and LITTLE, Richard, International systems in world politics: remaking the study of international relations (Oxford University Press, 2000).

CAMPOS, Raymundo Carlos Bandeira, Estudos de Historia: moderna e contemporanea (Atual, 1988).

CAREGNATO, Rita Catalina Aquino and MUTTI, Regina, 'Pesquisa Qualitativa: Analise de Discurso versus Analise de Conteudo', [2006] Texto Contexto Enferm, Out-Dez, 15 (4), pp. 679-684.

CARLSNEAS, Walter, RISSE, Thomas and SIMMONS, Beth A. (eds), Handbook of international relations, (Sage, 2003).

CAVALLARO, James, 'Towards fair play: a decade of transformation and resistance in International Human vol.09, nº. 04, Rio de Janeiro, 2016.pp. 2263-2311 2306 
Rights Advocacy in Brazil', [2002] University of Chicago Journal of International Law 3, pp. 481-492.

CHOULIARAKI, Lilie and FAIRCLOUGH, Norman, Discourse in Late Modernity: Rethinking Critical Discourse Analysis (Edinburgh University Press, 1999).

CORREA, Luiz Felipe de Seixas A palavra do Brasil nas Nações Unidas: 1946-1995 (FUNAG, 1995)

Dagnino, Evelina, 'An Alternative World Order and the Meaning of Democracy' in BRECHER, Jeremy, CHILDS, John Brown, and CUTLER, Jill (eds.), Global Visions: Beyond the New World Order (South End Press, 1993).

'Os movimentos sociais e a emergência de uma nova noção de cidadania' in DAGNINO, Evelina (ed), Anos 90: Política e Sociedade no Brasil (Editora Brasiliense, 1994).

'Culture, Citizenship, and Democracy: Changing Discourses and Practices of the Latin American Left' in ALVAREZ, Sonia E.; DAGNINO, Evelina and ESCOBAR, Arturo (eds.), Culture of Politics, Politics of Culture: Re-visioning Latin American Social Movements (Westview Press, 1998).

'Cultura, cidadania e democracia: a transformação dos discursos e práticas na esquerda latino-americana', in ALVAREZ, Sônia E. et al. (Eds.), Cultura e política nos movimentos sociais latino-americanos: novas leituras (Ed. UFMG, 2000).

'Os movimentos sociais e a construção da democracia no Brasil: Tendências recentes' [2001] JILAS -

Journal of Iberian and Latin American Studies, 7:1, July, pp. 75-104.

'Citizenship: a perverse confluence' [2007] Development in Practice, Vol. 17, No 4/5, pp. 549-556.

DOIMO, Ana Maria, A Vez e a Voz do Popular: Movimentos Sociais e Participacao Politica no Brasil Pos-70 (Relume-Dumara/ANPOCS, 1995).

DORIA, Palmerio, Honoráveis Bandidos: um retrato do Brasil na era Sarney (Geracao Editorial, 2009).

E/CN.4/2006/95/Add.5, Paragraph 246, page 50. Office of the United Nations High Commissioner for Human Rights <http://www2.ohchr.org/english/bodies/chr/docs/62chr/E.CN.4.2006.95.Add.5_.pdf> accessed 16 May 2016.

FAIRCLOUGH, Norman L., 'Critical and Descriptive Goals in Discourse Analysis', [1985] Journal of Pragmatics, 9, pp. 739-63.

FEINBERG, Richard (ed), Civil Society and Democracy in Latin America (Palgrave Macmillan, 2006).

FENWICK, Tracy Beck, 'Avoiding Governors: The Success of Bolsa Familia', [2009] Latin American Research Review 44 (1), pp. 102-131.

FERREIRA, Maria Cristina Leandro, 'O Quadro Atual da Análise do Discurso no Brasil', [2003] Cadernos de Comunicação (UFSM), v. 1, pp. 39-46.

FLYNN, Peter, 'Brazil: the Politics of the Cruzado Plan', [1986] Third World Quarterly 8(4), pp. 1151-1194.

'Brazil and Lula, 2005: Crisis, Corruption and Change in Political Perspective', [2005] Third World Quarterly 26(8),pp. 1221-1267.

FOWLER, Roger; HODGE, Bob; KRESS, Gunther; and TREW, Tony; Language and Control (Routledge \& Kegan, 1979).

FRASER, Nancy, 'Social Justice in the Age of Identity Politics: Redistribution, Recognitions, and Participation', in vol.09, nº. 04, Rio de Janeiro, 2016. pp. 2263-2311 2307 
Larry Ray and Andrew Sayer (eds.), Culture and Economy after the Cultural Turn (Sage Publications, 1999).

FRIEDMAN, Gil and STARR, Harvey, Agency, Structure, and International Politics: from ontology to empirical inquiry (Routledge, 1997).

GASPARI, Elio, Ditadura Derrotada, A - vol. 3 (Companhia das Letras, 2003).

GOHN, Maria da Gloria, Teorias dos Movimentos Sociais: paradigmas clássicos e contemporâneos (Loyola, 1997).

GONÇALVES, Maria de Fatima da Costa, A reinvenção do Maranhão Dinástico (Edicoes UFMA, 2000).

GOODMAN, Ryan and JINKS, Derek 'How to Influence States: Socialization and International Human Rights Law' [2004] Duke Law Journal, Volume 54 Issue 3 (Dec., 2004) 626.

GRAMSCI, Antonio, Escritos Políticos (volume I) (Civilizacao Brasileira, 2004).

GUDAVARTHY, Ajay, 'Introduction: Why Interrogate Political Society?', in Ajay Gudavarthy (ed.), Re-framing Democracy and Agency in India: Interrogating Political Society (Anthem Press, 2012).

GUZZINI, Stefano and LEANDER, Anna, Constructivism and International Relations: Alexander Wendt and his critics, (Routledge, 2006).

HAFNER-BURTON, Emilie M., 'Sticks and Stones: Naming and Shaming the Human Rights Enforcement Problem', [2008] International Organization 62, pp. 689-716.

HALL, Anthony, 'From Fome Zero to Bolsa Familia: Social Policies and Poverty Alleviation under Lula', [2006] Journal of Latin American Studies 38 (4), pp. 689-709.

HOLLIS, Martin and SMITH, Steve; Explaining and Understanding International Relations (Oxford University Press, 1991).

HUNTER, Wendy and POWER, Timothy J. 'Rewarding Lula: Executive Power, Social Policy, and the Brazilian Elections of 2006, [2007] Latin American Politics and Society 49 (1), pp. 1-30.

KATZENSTEIN et al. (eds), Exploration and contestation in the study of world politics, (MIT Press, 1999).

KECK, Margaret E. and SIKKINK, Kathryn; Activists beyond Borders: advocacy networks in international politics (Cornell University Press, 1998).

KLOTZ, Audie and LYNCH, Cecilia, Strategies for Research in Constructivist International Relations, (M. E. Sharpe, 2007).

KOERNER, Andrei, “O Papel dos Direitos Humanos na Politica Democratica: uma analise preliminar", [2003] RBCS 53 (18), pp. 143-157.

LAFER, Celso, A Reconstrução dos Direitos Humanos: um Dialogo com o pensamento de Hannah Arendt (Cia. das Letras,1988). 
LUNA, Francisco Vidal and KLEIN, Herbert S.; Brazil since 1980 (Cambridge University Press, 2006).

MACAULAY, Fiona, 'Justice-Sector and Human Rights Reform under the Cardoso Government', [2007] Latin American Perspectives, Issue 156, Vol. 34 No. 5, pp. 26-42.

MAGALHÃES, Izabel, 'Introdução: A Analise de Discurso Critica', [2005] D.E.L.TA, 21 Especial, pp. 1-9.

MARTINS FILHO, Ives Gandra, História do Brasil: Resumo Esquemático (LTR Editora, 2011).

MCCANN, Bryan, The Throes of Democracy: Brazil since 1989 (Zed Books, 2008).

MEADE, Teresa A., A Brief History of Brazil (Facts on File, 2010).

MENDES, Gilmar Ferreira, Coelho, Inocêncio Mártires, and BRANCO, Paulo Gustavo Gonet; Curso de Direito Constitucional (Saraiva 2008).

MOSER, Caroline O. N. and MCILWAINE, Cathy, 'Latin American Urban Violence as a Development Concern: Towards a Framework for Violence Reduction', [2006] World Development Vol. 34 (1), pp. 89-112.

NOGUEIRA, Conceicao, 'A Analise do Discurso' in L Almeida and E Fernandes (eds.), Metodos e Tecnicas de Avaliacao: novos contributos para a pratica e investigacao (Braga: CEEP, 2001).

OEA. Inter-American Commission on Human Rights. Report on the situation of human rights in Brazil 1997 / Inter-American Commission on Human Rights. OEA/Ser.L/V/II.97 GENERAL SECRETARIAT. WASHINGTON, D.C. 2006 Internet: http://www.cidh.org. Doc. 29 rev. 1. 29 September 1997, paragraph 9. Organization of American States (OAS) <http://www.oas.org/en/> accessed 9 May 2015.

OLIVEIRA, Francisco de, Critica a Razão Dualista: O Ornitorrinco (Boitempo, 2003).

'Privatização do público, destituição da fala e anulação da política: o totalitarismo neoliberal' In OLIVEIRA, Francisco and PAOLI, Maria Célia (eds), Os sentidos da democracia: políticas do dissenso e hegemonia global (Petrópolis: Vozes 1999).

PANIZZA, Francisco 'Neopopulism and its limits in Collor's Brazil', [2000] Bulletin of Latin American Research 19, pp. 177-192.

PANIZZA, Francisco and BRITO, Alexandra Barahona de, "The Politics of Human Rights in Democratic Brazil: A Lei nao Pega', [1998] Democratization, Vol. 5, No. 4, pp. 20-51.

PAULA, Marilene de (org), Nunca Antes na Historia desse Pais? Um Balanço das Politicas do Governo Lula (Fundação Heinrich Böll, 2011).

PEREIRA, Anthony W., Political (In)Justice: Authoritarianism and the Rule of Law in Brazil, Chile, and Argentina (University of Pettsburgh Press, 2005).

'The Dialectics of the Brazilian Military Regime's Political Trials' [2005] Luso-Brazilian Review Vol. 41, No 02, pp. 162-183.

'Explaining Judicial Reform Outcomes in New Democracies: The Importance of Authoritarian Legalism in Argentina, Brazil and Chile' [2003] Human Rights Review, Vol. 4, No. 3, pp. 3-16.

'Political Justice under Authoritarian Regimes in Argentina, Brazil and Chile' [2003] Human Rights Review, Vol 4, No. 2, pp. 27-47. 
PICQ Manuela Lavinas, The Politics of Human Rights in Brazil: Imposition of Norms From Without or Innovation From Within? (PhD International Studies Dissertation, December 2004, University of Miami).

PINHEIRO, Paulo Sergio, 'Democratic Consolidation and Human Rights in Brazil', [1998] Working Paper 256 Kellogg Institute (The Helen Kellogg Institute for International Studies), pp. 1-45. Available at <http://kellogg.nd.edu/publications/workingpapers/WPS/256.pdf> accessed 9 May 2016.

'Brazil and the International Human Rights System', [1999] Working Paper CBS-15-00 (P) University of

Oxford Centre for Brazilian Studies, pp. 1-46. Available at <http://www.brazil.ox.ac.uk/__data/assets/pdf_file/0005/9419/pinheiro15.pdf> accessed 8 May 2016.

PIOVESAN, Flávia, Direitos humanos e o direito constitucional internacional (São Paulo: Max Limonad 2008).

POTTER, Jonathan and WETHERELL, Margaret; Discourse and Social Psychology: Beyond Attitudes and Behaviour (Sage Publications, 1987).

PRIORE, Mary Del and VENÂNCIO, Renato, Uma Breve História do Brasil (Planeta do Brasil, 2010).

PRONER, Carol, CITTADINO, Giselle, TENENBAUM, Marcio, and RAMOS FILHO, Wilson (orgs.), A Resistência ao Golpe de 2016 (Projeto Editorial Praxis, 2016)

RABOSSI, Eduardo, 'La Teoria de los Derechos Humanos Naturalizada', [1990] Revista del Centro de Estudios Constitucionales (Madrid) 5, January-March, pp. 159-179.

RISSE, Thomas and SIKKINK, Kathryn 'The socialization of international human rights norms into domestic practices: introduction' in RISSE, Thomas, ROPP, Stephen C., and SIKKINK, Kathryn (eds), The Power of Human Rights: International Norms and Domestic Change (Cambridge University Press 1999);

RISSE, Thomas, ROPP, Stephen C., and SIKKINK, Kathryn, The Persistent Power of Human Rights: From Commitment to Compliance (Cambridge University Press, 2013).

SARAIVA, Mirian Gomes, 'Brazilian Foreign Policy towards South America during the Lula Administration: Caught between South America and Mercosur'. [2010] Revista Brasileira de Politica Internacional 53, pp. 151168.

SARLET, Ingo Wolfgang, A Eficácia dos Direitos Fundamentais (Livraria do Advogado, 2005).

Dignidade da Pessoa Humana e Direitos Fundamentais na Constituição Federal de 1988 (Livraria do Advogado, 2004).

SEMERARO, Giovanni, Gramsci e a sociedade civil: cultura e educação para a democracia (Vozes, 1999).

SILVA, Jose Afonso da, 'A Dignidade da Pessoa Humana como Valor Supremo da Democracia', [1998] Revista de Direito Administrativo, v. 212, pp. 84-94.

SIMIONATTO, Ivete, Gramsci: sua teoria, incidência no Brasil, influência no serviço social (Cortez, 1995).

SOARES, L. E. (1990). Os dois corpos do presidente. In Politica econômica: implicações éticas e políticas (pp. 16-22). Grupo de Conjuntura no. 28 (maio) IUPERJ (Rio de Janeiro). 
TERTO NETO, Ulisses, Protecting Human Rights Defenders in Brazil: A Legal and Socio-Political Analysis of the Brazilian Programme for the Protection of Human Rights Defenders (PhD Thesis, University of Aberdeen, 2016). a

'Law and the Protection of Human Rights Defenders: An Analysis of the Brazilian Legal Framework for the Protection of Human Rights Defenders' [2016] Revista Direito UFMS, forthcoming. b

A Politica Publica de Assistência Jurídica: a Defensoria Publica no Maranhão como Reivindicação do Campo Democrático Popular (Jurua, 2010).

TETI, Andrea, 'Democracy Without Social Justice: Marginalization of Social and Economic Rights in EU Democracy Assistance Policy after the Arab Uprisings' [2015] Middle East Critique, 24:1, pp. 9-25.

"The EU's First Response to the "Arab Spring": A Critical Discourse Analysis of the Partnership for Democracy and Shared Prosperity’ [2012] Mediterranean Politics Volume 17, Issue 3, pp. $266-284$.

UN, Implementation of General Assembly Resolution 60/251 of 15 March 2006 Entitled "Human Rights Council", A/HRC/4/37/Add.2 of 19 December 2006, page 7 or paragraph 14. United Nations (UN) <http://www2.ohchr.org/english/> accessed 9 May 2016.

UNHCHR. Human rights defenders: protecting the right to defend human rights. Fact Sheet No. 29. Geneva: United Nations, 2004. United Nations (UN) <http://www.un.org/en/> accessed 20 May 2016.

VILELA, Elaine and NEIVA, Pedro, 'Temas e Regiões nas Politicas Externas de Lula e Fernando Henrique: Comparação do Discurso dos dois Presidentes', [2011] Revista Brasileira de Politica International 54 (2), pp. 7096.

WHITEHEAD, Laurence, The International Aspects of Democratization: Europe and the Americas (Oxford University Press, 2001).

WENDT, Alexander, Social Theory of International Politics (Cambridge University Press, 2010).

Trabalho enviado em 21 de outubro de 2016.

Aceito em 01 de novembro de 2016. 